\title{
38. PETROLOGY OF VOLCANIC ROCKS FROM THE FORE-ARC SITES ${ }^{1}$
}

\author{
Arend Meijer, Elizabeth Anthony, and Mark Reagan, Department of Geosciences, \\ University of Arizona, Tucson, Arizona
}

\begin{abstract}
Late Eocene and Oligocene submarine lavas recovered along the Mariana arc-trench slope appear to represent an early stage of arc volcanism along the Palau-Kyushu-Mariana trend. At Site $458,90 \mathrm{~km}$ west of the Mariana Trench, the oldest lavas recovered were two pyroxene andesites with chemical and mineralogic characteristics generally associated with the arc tholeiite series. These are overlain by an unusual series of pyroxene (bronzite) andesites with relatively high $\mathrm{Mg}, \mathrm{Ni}$, and $\mathrm{Cr}$ and very low $\mathrm{Ti}, \mathrm{Zr}, \mathrm{Y}$, and REE contents. Lavas with similar characteristics from the Bonin Islands have been called boninites. Because the Site 458 samples show a wider range of textures than is commonly attributed to boninites, the term "boninite series" is suggested for the purpose of discussion. These lavas probably derived from wet partial melting of very depleted mantle materials overlying the Palau-Kyushu-Mariana subduction zone. In Hole 459B, $50 \mathrm{~km}$ west of the trench, all the lavas recovered have the general chemical characteristics of arc tholeiite series andesites. Petrographically, volcanic cobbles recovered in sedimentary deposits on the lower trench slope at Sites 460 and 461 (Holes 460, 460A, 461, and 461A) 23 and $11 \mathrm{~km}$, respectively, from the trench axis are similar to Hole 459B lavas. Chemical data for samples from these sites are compatible with this association.

All the volcanic rocks recovered show evidence of secondary alteration. Secondary minerals include clays, carbonate, zeolite, cristobalite, quartz, tridymite, celadonite, chlorite/clay, Fe-hydroxides, and other minor phases. In spite of the alteration, primary phases including pyroxenes, plagioclase, Fe-Ti-oxides, and glass remain unaltered in some samples. This type of alteration is similar to that observed in typical seafloor volcanic sections in the major ocean basins. No evidence of high $\mathrm{P}$, low $\mathrm{T}$ metamorphic conditions has been uncovered.

The proximity of arc-related volcanic rocks to the trench axis is difficult to explain in terms of current models of subduction complexes. Possible causes include magma generation at shallow depths along the Eocene-Oligocene subduction zone and tectonic erosion of the lower trench slope.
\end{abstract}

\section{INTRODUCTION}

The igneous rocks recovered from the Mariana forearc region during Leg 60 drilling represent the most extensive recovery of fore-arc "basement" rocks to date by DSDP/IPOD. Holes 458 and 459B, respectively 90 and $50 \mathrm{~km}$ due west of the Mariana Trench, provide us with a rare opportunity to study the in situ "basement" rocks of an active oceanic fore-arc region. An understanding of the nature and origin of such rocks is critical to the development of realistic models for the evolution of subduction complexes and, in the case of the Mariana fore-arc sites, to the understanding of the evolution of early arc volcanism.

This chapter is devoted primarily to the presentation and discussion of petrographic, mineralogic, and geochemical data for samples from the fore-arc sites, with some consideration given to their petrologic and tectonic implications.

\section{HOLE 458}

The lower Oligocene(?) igneous section recovered from this hole is composed mainly of fine- to mediumgrained (0.1-0.5 mm max.), generally aphyric, high $\mathrm{Mg}$ (bronzite) andesites and andesites of the arc tholeiite series. Glassy chill rinds, presumably from pillowed flows, were also recovered at various levels in the hole. On the basis of shipboard observations, the igneous sec-

\footnotetext{
1 Initial Reports of the Deep Sea Drilling Project, Volume 60.
}

tion is subdivided into five petrographic units as shown in Figure 1. The essential difference among the units is the proportion of fine/glassy to medium-grained material, although other criteria, such as the degree of alteration, overall color, modal mineralogy, and extent of fracturing, were also considered. These criteria reflect physical processes and are therefore of considerable value even though they may have no direct significance with regard to the origin of the magmas from which these rocks were derived.

The density of fractures and veins observed in the cores recovered, combined with the rather low overall recovery rate, suggests most of the igneous rocks from this hole were originally highly fractured (e.g, see photos for Cores 41 and 48 in site chapter). Small-scale displacements were observed along high-angle fractures in some cores, but it is not clear what significance these have with regard to regional stress fields to which the subduction complex has been subjected.

\section{Mineralogy and Petrography}

\section{Primary Textures}

Petrographically, most of the rocks at this site are similar to seafloor basalts as drilled by DSDP/IPOD in the major ocean basins. Typical textures are shown in Plates 1 and 2. No schistose or other fabrics reflecting penetrative deformation were found, although slickensided surfaces were observed along several "shear" zones (Fig. 1). Among the more significant petrographic features observed were (1) unusual chill rind textures in 


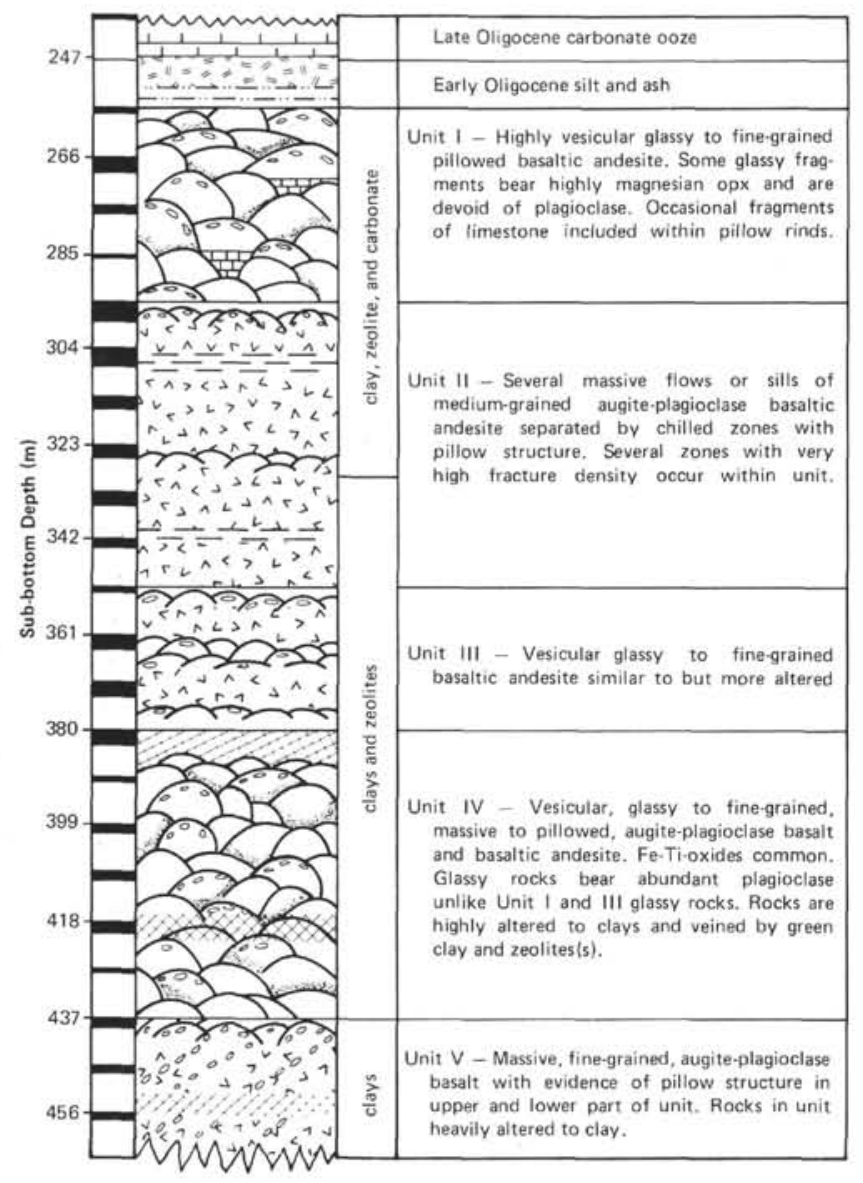

Figure 1. Igneous stratigraphy in Hole 458. Units I through V represent petrographic units. Percentage recovery of each 9-meter core interval indicated by shading in column to right of depth designation. Horizontal cross-hatching represents "sheared" intervals.

which abundant pyroxene occurs as the only primary crystalline phase, (2) a very low average phenocryst abundance ( $\leq 5 \mathrm{vol}, \%)$, (3) spherulitic intergrowths of quartz and $\mathrm{Fe}-\mathrm{Ti}$-oxide \pm plagioclase, and (4) a high average vesicularity.

The unusual chill rind textures occur among the pillowed bronzite andesites. They consist of small euhedral to acicular ( \pm "swallow tail") clinopyroxene microlites (Plate 1, Figs. 1, 2, and 5) and scattered clinopyroxene and orthopyroxene microphenocrysts (Plate 1, Fig. 3) set in a mesostasis of clear glass. Occasional brown vesicular "clots" occur in the glassy matrix. These are composed of very fine grained plagioclase, pyroxene, \pm an oxide phase and apparently represent localized centers of degassing (Plate 1, Fig. 5). The vesicles in these clots are irregular and very small $(0.05-0.1 \mathrm{~mm})$.

The chill rinds also contain large spherical to ellipsoidal vesicles $(0.5-1.5 \mathrm{~cm})$ near their margins (Plate 1 , Fig. 5). These are occasionally lined with zeolites and other secondary minerals (Plate 3, Fig. 4). The vesicularity of the rinds is often as high as 30 to $40 \mathrm{vol} . \%$ and implies substantial volatile contents at time of eruption. The fine- to medium-grained samples show a wide range of vesicularity $(5-45 \%)$ which is roughly correlated with the inverse of their grain size. In general the vesicles are not filled but are often lined with clay minerals \pm cristobalite. The abundance and form of the vesicles (Plate 2, Fig. 1) in these samples are similar to those in interarc basin lavas dredged from the Mariana Trough (see site chapters for 454 and 456 ).

The groundmass of most of the intergranular and subophitic textured samples contain small "spherulites" comprised of submicroscopic fibers of a silica phase and minute stringers of an Fe-Ti-oxide phase (Plate 2, Figs. 2 and 3). These "spherulites" are generally nucleated on primary origin. During secondary alteration they are recrystallized to "buttons" of cristobalite and coarsergrained Fe-Ti-oxide (see Plate 4, Fig. 4).

\section{Primary Mineralogy}

The primary (igneous) minerals in rocks from this site include, in order of abundance, clinopyroxene, plagioclase, orthopyroxene, Fe-Ti-oxides, quartz(?), and a brown (Cr-rich) spinel. Clinopyroxene and rare orthopyroxene microphenocrysts occur in Petrographic Units I, II, III, and IV, although together they rarely constitute more than 3 vol. $\%$ of the rock. Plagioclase and clinopyroxene microphenocrysts occur in nearly equal proportions in Petrographic Unit V and Core 41 of Unit IV. Their combined abundance is generally also less than 2 to $3 \%$.

Analyses of pyroxene microphenocrysts $(0.2-0.4 \mathrm{~mm})$ from various levels in the hole, obtained by microprobe techniques, are listed in Table 1 and plotted in Figure 2. Because clinopyroxene microphenocrysts are not substantially altered in most of the rocks in this hole, the analyses probably represent primary compositions. Those from the upper part of the section (Cores 28, 30) are substantially more magnesian than those from Unit V (Core 47). This correlates with the higher whole-rock $\mathrm{MgO}$ contents of samples from the upper portion of the hole and implies higher eruption temperatures. Clinopyroxene also occurs as the dominant groundmass pyroxene and as overgrowths and exolution lamellae in orthopyroxene.

The orthopyroxene phenocrysts found in rocks from Unit I are of bronzite composition (Table 1; Fig. 2). Representative analyses of orthopyroxenes from the other units were not obtained either because of small grain size or alteration effects. The orthopyroxenes of Unit I commonly display complex zoning or twinning, as shown in Plate 2, Figure 4. Orthopyroxene with compositions and forms similar to those observed at this site have been described from the Bonin Islands (Kuroda and Shiraki, 1975), Papua (Dallwitz and others, 1966), and the southern Mariana Trench (Dietrich et al., 1978; Fig. 2). Rocks with these distinctive orthopyroxenes have been given the name "boninite" (Johanssen, 1939; Cameron et al., 1979). Unlike the latter two localities, however, enstatite has not been found in rocks from Hole 458.

Plagioclase is largely unaltered in rocks in this hole and shows a distinct difference in habit in the upper and lower portions of the section. In fine-grained or glassy rocks in the upper portion, it is either absent altogether (Plate 1) or occurs as spherulitic quench crystals inter- 
Table 1. Pyroxene analyses.

\begin{tabular}{|c|c|c|c|c|c|c|c|c|c|c|c|c|c|c|c|c|c|}
\hline \multirow[b]{2}{*}{$\begin{array}{c}\text { Sample } \\
\text { (interval in } \mathrm{cm} \text { ) }\end{array}$} & \multicolumn{13}{|c|}{ Clinopyroxene } & \multicolumn{4}{|c|}{ Orthopyroxene } \\
\hline & \multicolumn{2}{|c|}{$\begin{array}{c}458-28-1 \\
136-139\end{array}$} & \multicolumn{2}{|c|}{$\begin{array}{c}458-30-1 \\
45-49\end{array}$} & \multicolumn{2}{|c|}{$\begin{array}{c}458-33-1 \\
121-124\end{array}$} & \multicolumn{2}{|c|}{$\begin{array}{c}458-47-1 \\
94-98\end{array}$} & \multirow{2}{*}{$\begin{array}{c}\begin{array}{c}459 \mathrm{~B}-66-3, \\
22-26\end{array} \\
52.3\end{array}$} & \multicolumn{2}{|c|}{$\begin{array}{c}459 \mathrm{~B}-60-1, \\
46-48\end{array}$} & \multicolumn{2}{|c|}{$\begin{array}{c}459 \mathrm{~B}-65-1, \\
17-21\end{array}$} & \multicolumn{2}{|c|}{$\begin{array}{c}\text { 459B-72-1, } \\
138-141\end{array}$} & \multirow{2}{*}{$\begin{array}{c}458-43-2 \\
34-37 \\
55.66\end{array}$} & \multirow{2}{*}{$\begin{array}{c}458-44-1 \\
61-68 \\
56.96\end{array}$} \\
\hline $\mathrm{SiO}_{2}$ & 51.97 & 53.49 & 53.20 & 53.32 & 50.92 & 55.25 & 51.58 & 51.84 & & 50.66 & 54.44 & 51.33 & 50.12 & 48.25 & 52.63 & & \\
\hline $\mathrm{TiO}_{2}$ & 0.23 & 0.11 & n.d. & 0.10 & 0.31 & 0.06 & 0.35 & n.d. & 0.32 & 0.23 & 0.12 & 0.20 & 0.44 & 0.75 & 0.17 & 0.04 & 0.00 \\
\hline $\mathrm{Al}_{2} \mathrm{O}_{3}$ & 3.19 & 2.24 & 2.48 & 2.25 & 3.92 & 1.21 & 1.58 & 1.41 & 1.91 & 3.03 & 1.76 & 3.33 & 2.13 & 3.95 & 2.85 & 0.96 & 0.54 \\
\hline 'FeO' & 9.67 & 6.71 & 6.66 & 6.97 & 11.49 & 5.29 & 16.18 & 14.44 & 14.5 & 6.94 & 3.95 & 5.52 & 10.69 & 17.64 & 5.89 & 10.57 & 8.03 \\
\hline $\mathrm{MnO}$ & 0.17 & 0.16 & 0.19 & 0.18 & n.d. & n.d. & n.d. & n.d. & n.d. & n.d. & n.d. & n.d. & n.d. & n.d. & n.d. & 0.19 & 0.29 \\
\hline $\mathrm{MgO}$ & 17.33 & 18.21 & 17.79 & 18.89 & 13.02 & 18.03 & 13.81 & 13.58 & 15.57 & 16.10 & 18.23 & 16.60 & 12.92 & 11.89 & 16.92 & 30.35 & 31.70 \\
\hline $\mathrm{CaO}$ & 16.07 & 18.34 & 19.13 & 17.51 & 20.67 & 19.87 & 16.32 & 18.30 & 15.94 & 18.62 & 19.81 & 19.82 & 19.68 & 16.55 & 20.63 & 1.56 & 1.54 \\
\hline $\mathrm{Na}_{2} \mathrm{O}$ & 0.11 & 0.13 & 0.11 & 0.12 & 0.15 & 0.09 & 0.21 & 0.17 & 0.21 & 0.28 & 0.21 & 0.14 & 0.23 & 0.26 & 0.16 & 0.00 & 0.02 \\
\hline $\mathrm{K}_{2} \mathrm{O}$ & n.d. & n.d. & 0.04 & 0.03 & 0.03 & 0.03 & 0.03 & 0.03 & 0.03 & 0.08 & 0.03 & 0.03 & 0.03 & 0.03 & 0.03 & 0.02 & 0.03 \\
\hline $\mathrm{P}_{2} \mathrm{O}_{5}$ & n.d. & n.d. & 0.38 & 0.03 & n.d. & n.d. & n.d. & n.d. & n.d. & n.d. & n.d. & n.d. & n.d. & n.d. & n.d. & 0.01 & 0.01 \\
\hline $\mathrm{Cr}_{2} \mathrm{O}_{3}$ & 0.03 & 0.42 & n.d. & n.d. & n.d. & n.d. & n.d. & n.d. & n.d. & n.d. & n.d. & n.d. & n.d. & n.d. & n.d. & 0.42 & n.d. \\
\hline Total & 98.77 & 99.81 & 99.98 & 99.40 & 100.50 & 99.84 & 100.07 & 99.78 & 100.79 & 95.95 & 98.56 & 96.95 & 96.24 & 99.32 & 99.34 & 99.77 & 99.11 \\
\hline "state" & $\begin{array}{l}f, g, b \\
0.2\end{array}$ & $\begin{array}{c}f, g, b \\
0.4\end{array}$ & $\begin{array}{l}f, m \\
0.2\end{array}$ & $\begin{array}{c}\mathrm{f}, \mathrm{m}, \mathrm{b} \\
0.8\end{array}$ & $\begin{array}{l}\mathrm{f}, \mathrm{o}, \mathrm{b} \\
1.5\end{array}$ & $\begin{array}{l}\mathrm{f}, \mathrm{o} \\
-\cdots\end{array}$ & $\begin{array}{r}\text { b,p, } \\
0.5\end{array}$ & $\begin{array}{l}\mathrm{b}, \mathrm{p}, \\
0.3\end{array}$ & $\begin{array}{l}\mathrm{f}, \mathrm{g} \\
0.2\end{array}$ & $\begin{array}{l}\mathrm{e}, \mathrm{g} \\
0.2\end{array}$ & $\begin{array}{l}e, g \\
0.1\end{array}$ & $\begin{array}{c}\mathrm{e}, \mathrm{m} \\
0.3\end{array}$ & $\begin{array}{l}\mathrm{e}, \mathrm{m}, \\
0.6\end{array}$ & $\begin{array}{l}f, g, b \\
0.3\end{array}$ & $\begin{array}{l}\mathrm{f}, \mathrm{m}, \\
0.2\end{array}$ & $\begin{array}{l}\mathrm{f}, \mathrm{s}, \\
0.4\end{array}$ & $\begin{array}{l}\text { f,p, } \\
1.0\end{array}$ \\
\hline
\end{tabular}

Note: $\mathrm{b}=$ bladed, $\mathrm{e}=$ etched, $\mathrm{f}=$ fresh, $\mathrm{g}=$ groundmass, $\mathrm{m}=$ microphenocryst, $\mathrm{o}=$ ophitic or subophitic, $\mathrm{p}=$ phenocryst, $\mathrm{s}=$ skeletal, $0.2=$ maximum dimension in mm.

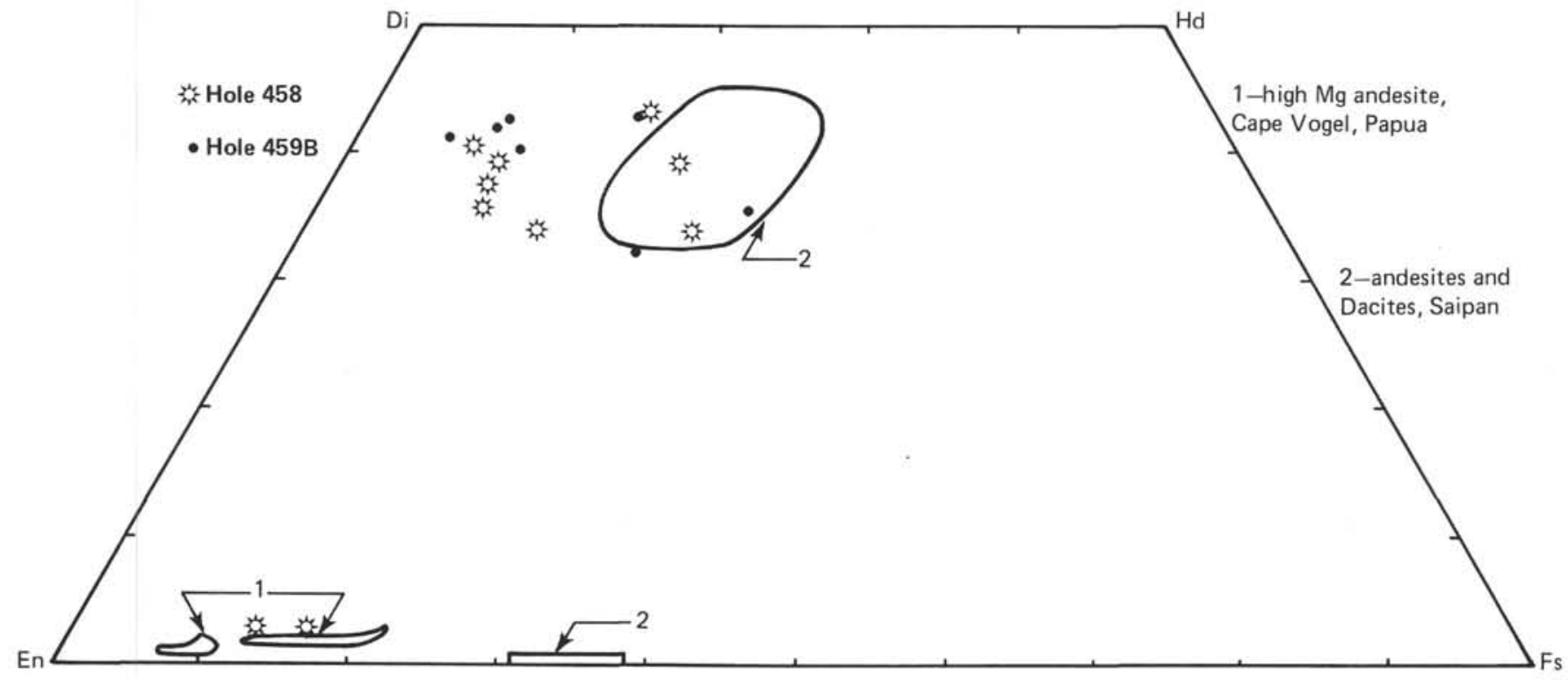

Figure 2. Plot of pyroxene compositions for samples from Holes 458, 459B, Saipan and Papua, New Guinea. Saipan analyses by optical methods from Schmidt (1957). Papua analyses by microprobe from Dallwitz and others (1965). See Table 1 for details of new analyses.

grown with clinopyroxene (Plate 3, Fig. 1). In finegrained rocks of the lower portion, it occurs as phenocrysts and as the main crystalline phase in the groundmass (Plate 3, Fig. 2). This difference in habit is probably a function of differences in magma chemistry, as discussed later. Coarser-grained rocks from the upper portion contain abundant, coarsely crystalline plagioclase intergrown with clinopyroxene (Plate 2, Figs. 2 and 3; Table 2, Sample 458-33-1, 121-124 cm), suggesting that some factor $\left(\mathrm{P}_{\mathrm{H}_{2} \mathrm{O}}\right.$ ?) inhibited plagioclase crystallization in the fine-grained rocks of this portion. Analyses of plagioclase phenocrysts presented in Table 2 range from $\mathrm{An}_{63}$ to $\mathrm{An}_{76}$. No albite was found in the samples studied.

In the upper portion of the section, the presence or absence and the size of the Fe-Ti-oxide phase are generally a direct function of the crystallinity of the matrix in any particular rock. The pillow rinds have none, whereas the microdiabases have up to $5 \%$ of discrete
0.02 to $0.05 \mathrm{~mm}$ crystals in addition to the "stringers" in the quartz-plagioclase spherulites (Plate 2, Figs. 2 and 3 ). In the lower portion of the section (Unit V) a discrete oxide phase is evident in even the finest-grained samples (Plate 3, Fig. 2), presumably due to the higher total iron content of these rocks (see site chapter). No analyses of oxide phases were obtained for samples from this hole.

A brown spinel phase is occasionally found as octahedra included in clinopyroxene microphenocrysts. No analyses were obtained. No sulfide phases were identified in any of the samples from this hole, but flecks of native copper occur as part of a vein filling in a sample from Core 39 (458-39-1, 81-84 cm).

\section{Secondary Mineralogy}

The effects of alteration and diagenesis are evident throughout the cored section. Secondary minerals tentatively identified in thin section include various smec- 
Table 2. Plagioclase analyses.

\begin{tabular}{|c|c|c|c|c|c|c|c|c|c|c|c|c|c|c|c|c|}
\hline \multirow{2}{*}{$\begin{array}{c}\begin{array}{c}\text { Sample } \\
\text { (interval in } \mathrm{cm} \text { ) }\end{array} \\
\mathrm{SiO}_{2}\end{array}$} & \multirow{2}{*}{$\begin{array}{c}\begin{array}{r}458-33-1 \\
121-124\end{array} \\
52.65\end{array}$} & \multicolumn{3}{|c|}{$\begin{array}{c}458-46-1 \\
100-106\end{array}$} & \multicolumn{2}{|c|}{$\begin{array}{c}458-47-1 \\
94-98\end{array}$} & \multicolumn{2}{|c|}{$\begin{array}{c}459 \mathrm{~B}-60-1, \\
46-48\end{array}$} & \multicolumn{2}{|c|}{$\begin{array}{c}459 \mathrm{~B}-65-1, \\
17-21\end{array}$} & \multirow{2}{*}{$\begin{array}{c}\begin{array}{c}459 \mathrm{~B}-66-2 \\
22-26\end{array} \\
53.76\end{array}$} & \multicolumn{3}{|c|}{$\begin{array}{c}459 \mathrm{~B}-71-1 \\
142-145\end{array}$} & \multicolumn{2}{|c|}{$\begin{array}{c}459 \mathrm{~B}-72-1 \\
138-141\end{array}$} \\
\hline & & 53.00 & 51.45 & 51.30 & 52.34 & 51.42 & 49.19 & 50.21 & 48.09 & 51.95 & & 56.05 & 54.98 & 53.52 & 49.67 & 54.14 \\
\hline $\mathrm{TiO}_{2}$ & 0.04 & 0.00 & 0.10 & 0.06 & 0.72 & 0.03 & 0.04 & 0.01 & 0.11 & 0.06 & 0.01 & 0.04 & n.d. & 0.10 & 0.04 & 0.07 \\
\hline $\mathrm{Al}_{2} \mathrm{O}_{3}$ & 32.42 & 30.33 & 31.01 & 31.65 & 31.40 & 28.3 & 26.64 & 31.83 & 34.25 & 29.41 & 31.36 & 27.49 & 27.05 & 27.87 & 28.70 & 29.39 \\
\hline 'FeO' & 0.94 & 0.77 & 0.95 & 0.74 & 1.52 & 0.74 & n.d. & 0.76 & 0.89 & 1.08 & 1.07 & 0.87 & 0.76 & 1.28 & n.d. & 1.04 \\
\hline $\mathrm{MnO}$ & n.d. & 0.00 & 0.00 & 0.00 & n.d. & n.d. & n.d. & n.d. & 0.01 & n.d. & n.d. & n.d. & n.d. & n.d. & n.d. & n.d. \\
\hline $\mathrm{MgO}$ & 0.14 & 0.07 & 0.09 & 0.09 & 0.11 & 0.08 & 0.12 & 0.19 & 0.06 & 0.20 & 0.12 & 0.10 & 0.06 & 0.17 & 0.17 & 0.11 \\
\hline $\mathrm{CaO}$ & 15.06 & 13.19 & 13.85 & 14.51 & 13.26 & 12.41 & 14.24 & 15.55 & 17.06 & 13.27 & 13.68 & 12.03 & 10.41 & 12.52 & 13.15 & 12.21 \\
\hline $\mathrm{Na}_{2} \mathrm{O}$ & 2.79 & 3.40 & 3.08 & 2.57 & 3.66 & 3.92 & 2.46 & 2.54 & 1.80 & 3.99 & 3.76 & 4.56 & 5.35 & 4.17 & 3.30 & 4.49 \\
\hline $\mathrm{K}_{2} \mathrm{O}$ & 0.07 & 0.05 & 0.10 & 0.05 & 0.10 & 0.06 & 1.84 & 0.06 & 0.04 & 0.06 & 0.05 & 0.10 & 0.08 & 0.07 & 0.07 & 0.10 \\
\hline $\mathrm{P}_{2} \mathrm{O}_{5}$ & n.d. & n.d. & 0.04 & 0.00 & n.d. & n.d. & n.d, & n.d. & 0.00 & n.d. & n.d. & n.d. & n.d. & n.d. & n.d. & n.d. \\
\hline Totala & 104.1 & 100.82 & 100.6 & 100.97 & 103.11 & 96.95 & 94.52 & 101.16 & 102.29 & 100.03 & 103.79 & 101.25 & 98.68 & 99.69 & 95.10 & 101.55 \\
\hline Mol $\%$ An & 75 & 68 & 73 & 76 & 66 & 63 & 68 & 77 & k4 & 65 & 67 & 59 & 52 & 62 & 69 & 60 \\
\hline "state" & $\begin{array}{l}\text { e,o, } \\
0.4\end{array}$ & $\begin{array}{l}\text { f,s. } \\
0.3\end{array}$ & $\begin{array}{r}\mathrm{f}, \mathrm{s}, \\
0.25\end{array}$ & $\begin{array}{r}f, 5, \\
0.25\end{array}$ & $\begin{array}{l}\text { e,m, } \\
0.2\end{array}$ & $\begin{array}{l}\mathrm{e}, \mathrm{m}, \\
0.3\end{array}$ & $\begin{array}{l}\text { e.o. } \\
0.2\end{array}$ & $\begin{array}{l}\text { e,o, } \\
0.5\end{array}$ & $\begin{array}{l}\text { e.m. } \\
0.7\end{array}$ & $\begin{array}{l}\text { e,s, } \\
0.3\end{array}$ & $\begin{array}{l}\text { e,o, } \\
0.4\end{array}$ & $\begin{array}{l}\text { e,g. } \\
0.1\end{array}$ & $\begin{array}{l}\text { e,g, } \\
0.4\end{array}$ & $\begin{array}{l}\text { e,g. } \\
0.2\end{array}$ & $\begin{array}{l}\text { e,g. } \\
0.6\end{array}$ & $\begin{array}{l}\text { e.g. } \\
0.2\end{array}$ \\
\hline
\end{tabular}

Note: "State" symbols same as Table 1.

a poor totals due to small grain size and/or alteration.

tite/illite series clays, interlayered chlorite/clay, celadonite, carbonate, zeolite, and minor hydrous iron oxides. Of the primary (igneous) phases, clinopyroxene, plagioclase, Fe-Ti-oxide, and quartz(?) remain largely unaltered, whereas groundmass orthopyroxene and interstitial glass have been largely replaced.

Although no effort was made to identify the various clay minerals in these rocks, the variations in color suggest a number of different types are present. The colors of clays which occur as vesicle linings vary from light green or aquamarine in Unit I, to light gray in Units II and III, to dark green in Unit IV and chocolate brown in Unit V. These variations presumably reflect differences in composition and the oxidation state of iron. Clays lining veins are usually white to cream-colored and (rarely) apple green. Alteration of the glassy mesostasis has produced light olive green to brown clays. Pseudomorphs after orthopyroxene (Plate 3, Fig. 5) generally contain clays (interlayered chlorite-clay[?]) of slightly greener color than the clays in the adjacent mesostasis. Clays rarely fill vesicles entirely except in Unit V. Plate 3 , Figure 3 shows a vesicle lined with a brown clay and filled with green clay (celadonite?). A microprobe analysis of the brown clay is listed in Table 3 .

A carbonate phase is present in most of the cores from 28 to 35 . In the fine-grained samples the carbonate occurs as a vein filling, whereas in coarser-grained samples (e.g., Cores 32,33 ) it occurs as a vesicle and cavity filling. The composition of this phase was not determined.

Table 3. Analyses of secondary phases.

\begin{tabular}{crrrrrrr}
\hline $\begin{array}{c}\text { Sample } \\
\text { (interval in cm) }\end{array}$ & $\begin{array}{r}458-43-2, \\
34-37\end{array}$ & \multicolumn{2}{c}{$\begin{array}{c}458-46-1, \\
100-106\end{array}$} & $\begin{array}{c}459 \mathrm{~B}-66-3, \\
22-26\end{array}$ & $\begin{array}{c}459 \mathrm{~B}-72-1, \\
138-141\end{array}$ & \multicolumn{2}{c}{$\begin{array}{c}459 \mathrm{~B}-71-1, \\
142-145\end{array}$} \\
\hline $\mathrm{SiO}_{2}$ & 37.88 & 46.75 & 38.49 & 43.55 & 37.52 & 98.50 & 97.63 \\
$\mathrm{TiO}_{2}$ & 0.12 & 0.00 & 0.24 & 0.23 & 0.46 & 0.02 & 0.08 \\
$\mathrm{Al}_{2} \mathrm{O}_{3}$ & 12.88 & 11.03 & 10.58 & 3.71 & 3.13 & 0.28 & 0.29 \\
$\mathrm{FeO}^{\prime}$ & 0.00 & 24.56 & 17.67 & 12.56 & 32.6 & 0.12 & 0.14 \\
$\mathrm{MnO}$ & 0.02 & 0.09 & 0.14 & n.d. & n.d. & n.d. & n.d. \\
$\mathrm{MgO}$ & 0.12 & 6.40 & 4.45 & 4.9 & 5.04 & 0.02 & 0.07 \\
$\mathrm{CaO}$ & 1.52 & 2.47 & 2.53 & 0.08 & 0.65 & 0.04 & 0.04 \\
$\mathrm{Na}_{2} \mathrm{O}$ & 33.23 & 0.25 & 0.39 & 0.18 & 0.47 & 0.13 & 0.14 \\
$\mathrm{~K}_{2} \mathrm{O}$ & 2.47 & 1.04 & 1.24 & 6.84 & 2.7 & 0.03 & 0.06 \\
$\mathrm{P}_{2} \mathrm{O}_{5}$ & 0.00 & 0.00 & 0.03 & $n . d$. & $n . d$. & n.d. & n.d. \\
$\mathrm{Total}^{\mathrm{a}}$ & 88.24 & 92.59 & 75.78 & 72.05 & 82.56 & 99.16 & 98.18 \\
& zeolite & clay & clay & celadonite & stilpno- & cristobalite \\
& & & & & melane(?) & & \\
\hline
\end{tabular}

a Not including $\mathrm{H}_{2} \mathrm{O}, \mathrm{CO}_{2}$, etc.
Zeolites occur sporadically in the igneous section as a vein and vesicle filling (Plate 3, Fig. 4) primarily in the glassy chill rinds of pillowed flows. On the basis of microprobe analyses (Table 3) and an X-ray pattern the dominant zeolite appears to be phillipsite.

In summary, the secondary mineral assemblages observed in samples from this hole are similar to those observed in altered seafloor basalts from the major ocean basins (Bass and others, 1973; Bass, 1976; Scheidegger and Stakes, 1977) except that silica minerals are more common in rocks from this site. No consistent correlations between secondary mineral assemblages and depth have been discovered, although carbonate appears to be restricted to the upper portion of the section. The rocks in this section have clearly undergone diagenesis, as evidenced by the secondary mineral assemblages and changes in the whole-rock chemistry discussed in the following.

\section{Geochemistry}

Major and trace element analyses of samples selected from cores recovered from this hole (Tables 4-6, Wood et al., this volume) suggest the following: (1) Samples from petrographic Units I through IV are generally quartz normative, bronzite andesites enriched in refractory elements such as $\mathrm{Ni}, \mathrm{Cr}$, and $\mathrm{Mg}$ and depleted in "immobile" large ion lithophile (LIL) elements including $\mathrm{Ti}, \mathrm{Zr}, \mathrm{Y}$, and HREE, relative to andesites from other areas. (2) Samples from petrographic Unit V are also quartz normative but are substantially depleted in refractory elements and enriched in LIL elements relative to samples from overlying units. They have chemical characteristics common to the arc tholeiite series. (3) Secondary alteration has modified the original concentrations of most of the major elements and many trace elements, although comparison of whole-rock analyses of adjacent altered and unaltered material suggests firstorder trends are preserved in spite of the alteration. And (4) on the basis of variations in the concentrations of "immobile" elements, the degree of differentiation decreases upward in the section (i.e., with decreasing age).

The normative mineral abundances of altered and unaltered samples from this site are plotted in Figure 3 along with data for samples from Guam and a site south 


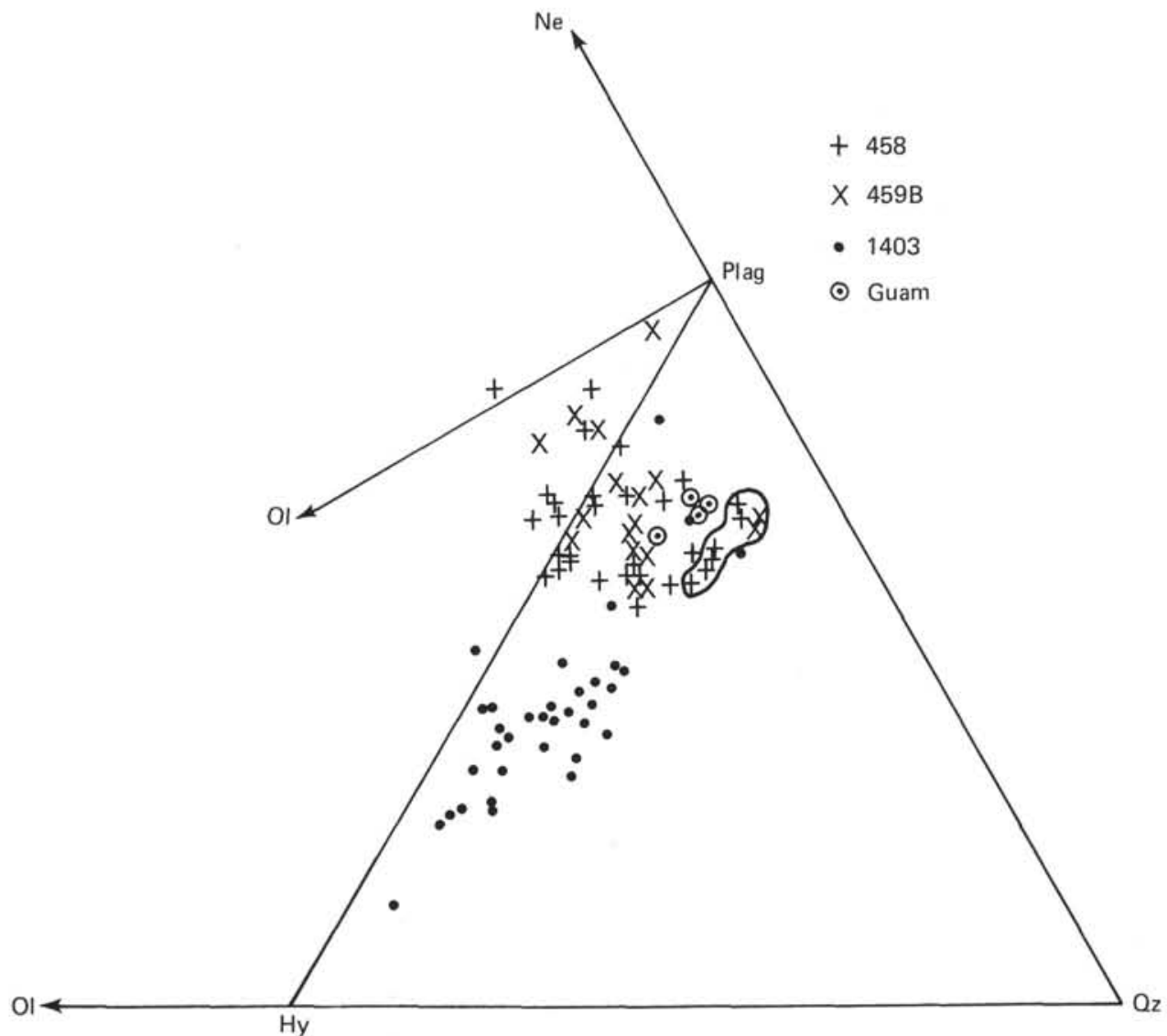

Figure 3. Normative mineral composition of Mariana fore-arc lavas. Samples from dredge site 1403, southeast of Guam from Sharaskin (in press). Details of Guam analyses to be published elsewhere. Closed curve contains analyses of unaltered samples from Holes 458 and 459B. Scatter of other 458 and $459 \mathrm{~B}$ analyses due primarily to secondary alteration. Normative mineralogy calculated assuming $\mathrm{Fe}_{2} \mathrm{O}_{3}=0.15 \mathrm{FeO}$

of Guam dredged in 1976 by the Dimitri Mendeleev (anonymous, 1977; Sharaskin, in press). Analyses of unaltered aphyric samples from Holes 458 and 459B consistently show on the order of 15 to $20 \%$ normative quartz (closed curve in Fig. 3), whereas analyses of altered samples from both holes show a large amount of scatter. This scatter is believed to be due primarily to secondary mobilization of components as discussed in the following section.

Samples from Petrographic Units I through IV generally have high $\mathrm{Mg} / \mathrm{Mg}+\Sigma \mathrm{Fe}$ (atom) ratios (50-60) relative to other types of andesites. Because the magmas these samples represent were probably modified by crystal fractionation of $\mathrm{Fe}-\mathrm{Mg}$ minerals after separation from their source materials (see discussion following), they may originally have had even higher ratios. Green (1976) has shown that melts with these characteristics can be produced by high degrees $(25-35 \%)$ of partial fusion of ultramafic material under hydrous conditions at 1000 to $1200^{\circ} \mathrm{C}$ and 10 to $20 \mathrm{kbar}$.

A discussion of the petrogenesis of these lavas requires analyses representative of their original (igneous) chemical compositions. Such analyses are difficult to obtain because most of the samples in this hole have been chemically altered by secondary processes. The material which appears most accurately to reflect orig- inal igneous compositions is found in the chill rinds of the pillowed flows. Although all of the rinds recovered from this hole show some degree of alteration, secondary phases in the rinds can be separated from primary (igneous) material by the use of heavy liquids, magnetic separation, and hand-picking. We have obtained what we believe to be unaltered aliquots $(50-500 \mathrm{mg})$ of pillow rind fragments from several levels in the hole. The aliquots are composed mainly of glass and quench crystals and are thought to closely approximate compositions of the lava at the time of consolidation. Portions of each aliquot were fused on an Mo strip furnace under an $\mathrm{Ar}$ atmosphere at $1750^{\circ} \mathrm{C}$ (Brown, 1976) to produce homogeneous glasses which were analyzed for major elements on a microprobe (see Appendix).

The results of the analyses are presented in Table 4. Values for loss on ignition, obtained from weight loss during fusion in the Mo strip furnace, are accurate to within $\pm 0.20 \%$ absolute. Relative to the conventional whole-rock analyses reported by Wood et al., this volume, the pillow rind analyses, although fewer in number, show much less variation. This is particularly evident in Figure 4, where both types of analyses are plotted relative to depth of recovery. The smaller variations evident in the pillow rind analyses correlate very well with the variations in "immobile" trace element con- 

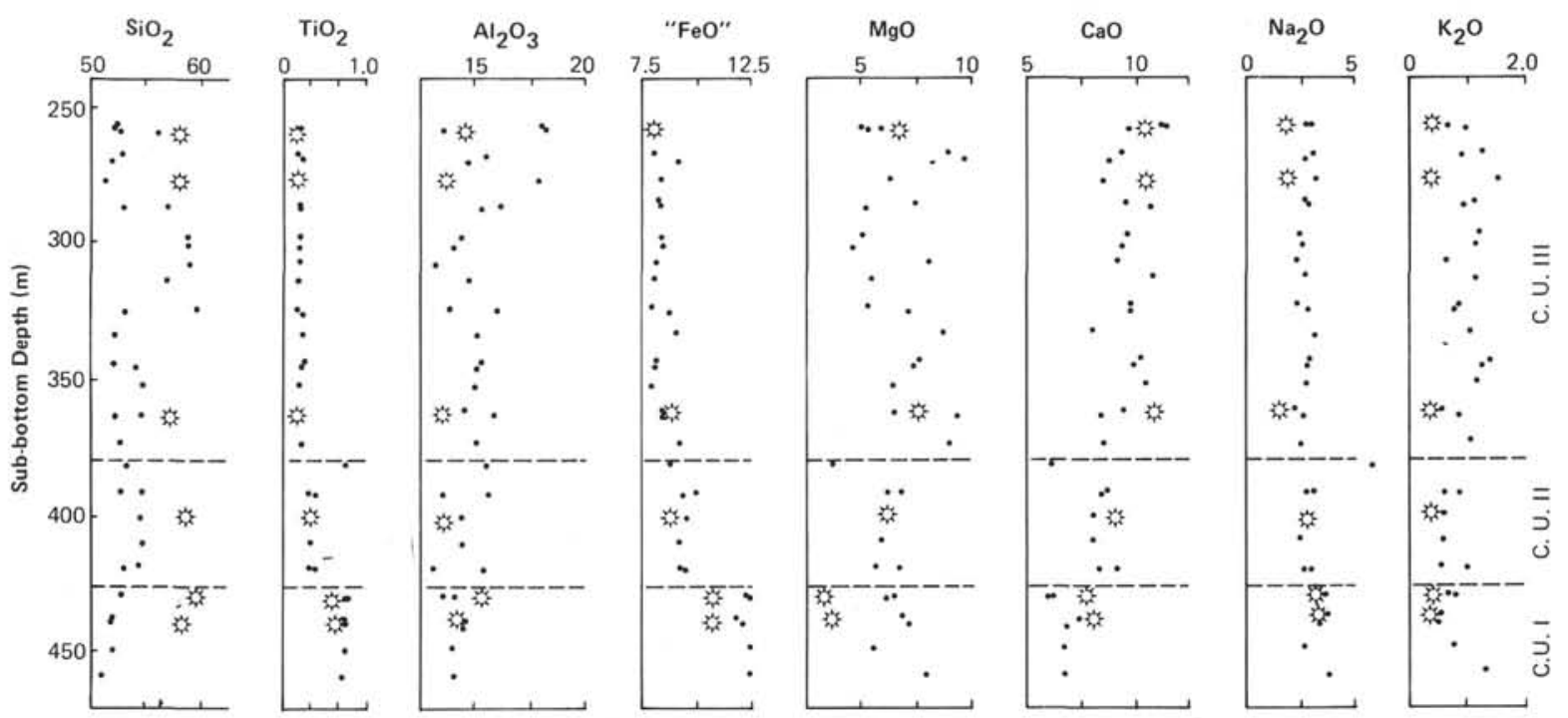

Figure 4. Major elements in wt. $\%$ vs. depth of recovery for samples from Hole 458. C.U. I through III are chemical units. Solid dots represent whole rock analyses of altered samples. Stars represent microprobe analyses of fused chill rind separates. Note depletion and enrichment of elements in altered samples relative to unaltered chill rind separates. "FeO" represents total Fe as $\mathrm{FeO}$.

centrations obtained by conventional whole-rock analyses of altered samples (compare with Fig. 5). Together, these data define at least three chemical units (C.U.): C.U. I includes petrographic Units I, II, and III; C.U. II corresponds to Petrographic Unit IV; and C.U. III corresponds to Petrographic Unit V. The extent of differentiation evident within these units decreases systematically upward in the section.

Analyses of primary glasses found in the chill rind samples are also listed in Table 4. Compared to the whole-rock (fusion) analyses, glass compositions directly reflect the crystallization of groundmass pyroxene.

The chemical effects of secondary alteration are clearly evident in Figure 4. Comparison of microprobe (fusion) analyses and conventional analyses of altered whole rocks suggests that $\mathrm{SiO}_{2}$, and to a lesser extent $\mathrm{CaO}$, were depleted by the alteration processes whereas $\mathrm{Na}_{2} \mathrm{O}, \mathrm{K}_{2} \mathrm{O}$, and $\mathrm{MgO}$ were variably enriched. The $\mathrm{Al}_{2} \mathrm{O}_{3}$ data suggest depletion in the upper parts of the section and enrichment in the lower part (C.U. III). This crossover trend and the increased depletion of $\mathrm{SiO}_{2}$ and enrichment of $\mathrm{MgO}$ downward in the section probably reflect higher alteration temperatures at depth. The minor systematic enrichment of $\mathrm{FeO}$ and $\mathrm{TiO}_{2}$ in the altered samples is mostly a result of constant volume density changes resulting from the alteration processes. As the mean atomic weight of a rock is decreased through the addition of $\mathrm{H}_{2} \mathrm{O}$ and other light elements, the relative concentrations of $\mathrm{FeO}_{1}$ and $\mathrm{TiO}_{2}$ are increased if they remain immobile.

Table 4. Whole-rock and glass analyses.

\begin{tabular}{|c|c|c|c|c|c|c|c|c|c|c|c|c|c|c|c|c|}
\hline & $1 \mathrm{a}$ & $2^{\mathrm{a}}$ & 36 & $4^{b}$ & $5 \mathrm{c}$ & $6 b$ & 76 & $8^{c}$ & $9^{a}$ & $10^{\mathrm{b}}$ & $11 \mathrm{c}$ & $12^{b}$ & $13^{\mathrm{b}}$ & $14 \mathrm{~b}$ & 15 & 16 \\
\hline \multicolumn{9}{|c|}{ Boninite Series } & \multicolumn{6}{|c|}{ Tholeiite Series } & \multicolumn{2}{|c|}{$\begin{array}{l}\text { Are Tholeite Series } \\
\text { Jakes and White (1972) }\end{array}$} \\
\hline $\begin{array}{c}\text { Sample } \\
\text { (interval in } \mathrm{cm} \text { ) }\end{array}$ & $\begin{array}{l}\text { (glassy) } \\
458-28-1, d \\
140-142\end{array}$ & $\begin{array}{c}\text { (cryst.) } \\
458-34-1 \text {. } \\
39-41\end{array}$ & $\begin{array}{l}458-28-1 \\
136-139\end{array}$ & $\begin{array}{c}458-30-1 . \\
45-49\end{array}$ & $\begin{array}{c}458-30-1 \\
45-49\end{array}$ & $\begin{array}{c}458-39-1 \\
23-26\end{array}$ & $\begin{array}{l}\begin{array}{l}458-43-1 \\
137-140\end{array}\end{array}$ & $\begin{array}{c}458-43-2, \\
34-37\end{array}$ & $\begin{array}{c}459 \mathrm{~B}-46-1 \\
75-77\end{array}$ & $\begin{array}{l}459 \mathrm{~B}-46-1 \\
100-106\end{array}$ & $\begin{array}{c}459 \mathrm{~B}-46-1 \\
100-106\end{array}$ & $\begin{array}{c}459 \mathrm{~B}-47-1, \\
94-98\end{array}$ & $\begin{array}{c}\text { 459B-65-1. } \\
34-38\end{array}$ & $\begin{array}{c}459 \mathrm{~B}-73-1 . \\
80-82\end{array}$ & Basalt & Andesite \\
\hline $\mathrm{SiO}_{2}$ & 56.1 & 56.9 & 57.99 & 57.88 & 57.64 & 57.18 & 58.47 & 58.64 & 52.8 & 59.28 & 59.32 & 58.06 & 59.30 & 59.58 & 51.89 & 59.19 \\
\hline $\mathrm{TiO}_{2}$ & 0.28 & 0.30 & 0.23 & 0.22 & 0.33 & 0.24 & 0.47 & 0.52 & 1.13 & 0.88 & 1.03 & 0.93 & 0.90 & 0.90 & 0.80 & 1.29 \\
\hline $\mathrm{Al}_{2} \mathrm{O}_{3}$ & 13,7 & 14.7 & 14.48 & 13.63 & 15.50 & 13.48 & 13.42 & 15.38 & 13.6 & 15,16 & 14.16 & 14.27 & 13.99 & 14.53 & 16.01 & 16.09 \\
\hline $\mathrm{FeO}_{4}$ & 8.39 & 8.06 & 8.03 & 8.14 & 7.53 & 8.78 & 8.76 & 8.02 & 12.45 & 10.61 & 10.82 & 10.70 & 10.34 & 9.43 & 9.57 & 8.39 \\
\hline $\mathrm{MnO}$ & 0.14 & 0.12 & n.d. & n.d. & 0.13 & n.d. & n.d, & 0.12 & 0.10 & n.d. & 0.18 & n.d. & n.d. & n.d. & 0.17 & - \\
\hline $\mathrm{MgO}$ & 6.11 & 5.53 & 6.71 & 6.34 & 5.04 & 7,56 & 6.10 & 4.56 & 6.17 & 3.06 & 2.36 & 3.59 & 3.43 & 3.41 & 6.77 & 3.48 \\
\hline $\mathrm{CaO}$ & 9.59 & 10.76 & 10.47 & 10.39 & 9.73 & 10.84 & 8.90 & 8.74 & 5.88 & 7.63 & 6.74 & 7.98 & 7.64 & 7,88 & 11.81 & 6.33 \\
\hline $\mathrm{Na}_{2} \mathrm{O}$ & 1.97 & 2.61 & 1.87 & 1.83 & 1.78 & 1.59 & 2.54 & 1.84 & 3.41 & 3.10 & 1.63 & 3.23 & 3.04 & 3.04 & 2.42 & 4.33 \\
\hline $\mathrm{K}_{2} \mathrm{O}$ & 0.44 & 1.12 & 0.35 & 0.35 & 0.35 & 0.30 & 0.39 & 0.35 & 0.75 & 0.35 & 0.31 & 0.36 & 0.28 & 0.32 & 0.44 & 0.44 \\
\hline $\mathrm{P}_{2} \mathrm{O}_{5}$ & 0.02 & 0.04 & n.d. & n.d. & 0.15 & n.d. & n.d. & 0.17 & 0.06 & n.d. & 0.10 & n.d. & n.d. & n.d. & 0.11 & 0.45 \\
\hline Total & 97.67 & 101.02 & 100.13 & 98.78 & 98.18 & 99.97 & 99.05 & 98.34 & 97.74 & 100.07 & 96.65 & 99.12 & 98.92 & 99.08 & 99.99 & 99.99 \\
\hline L.o.I. & - & - & 3.07 & 3.61 & - & 3.89 & 3.85 & - & - & 4.81 & - & 3.12 & 3.74 & 4.07 & - & - \\
\hline $\mathrm{Ni}(\mathrm{ppm})$ & 74 & 65 & - & - & - & - & - & - & 23 & - & - & - & - & - & 30 & 20 \\
\hline $\mathrm{Cr}(\mathrm{ppm})$ & 189 & 200 & - & - & - & - & - & - & iI & - & - & - & - & - & 50 & is \\
\hline$Y(\mathrm{ppm})$ & 7 & 9 & $=$ & $\overline{-}$ & $=$ & $\overline{-}$ & - & - & 20 & $=$ & $=$ & $=$ & $=$ & - & - & - \\
\hline $\mathrm{Zr}(\mathrm{ppm})$ & 28 & 30 & $28^{e}$ & $27^{e}$ & $27^{\mathrm{e}}$ & $35^{\mathrm{e}}$ & $51^{e}$ & $51^{e}$ & 65 & $68^{e}$ & $68^{\mathrm{e}}$ & $69^{\mathrm{e}}$ & $68^{e}$ & $66^{\mathrm{e}}$ & 70 & 70 \\
\hline $\mathrm{Ba}(\mathrm{ppm})$ & 33 & 47 & - & - & - & - & - & - & 63 & - & - & - & - & - & 75 & 100 \\
\hline $\mathrm{CaO} / \mathrm{TiO}_{2}$ & 34.2 & 35.9 & 45.5 & 47.2 & 29.5 & 45.2 & 18.9 & 16.8 & 5.2 & 8.7 & 6.5 & 8.6 & 8.5 & 8.8 & 14.8 & 4.9 \\
\hline $\mathrm{Al}_{2} \mathrm{O}_{3} / \mathrm{TiO}_{2}$ & 48.9 & 49.0 & 63.0 & 62.0 & 470 & 56.2 & 28.6 & 29.6 & 12.0 & 17.2 & 13.7 & 15.3 & 15.5 & 16.1 & 20.0 & 12.5 \\
\hline $\mathrm{TiO}_{2} / \mathrm{Zr}$ & 100 & 100 & 82 & 81 & 122 & 83 & 92 & 102 & 174 & 135 & 151 & 135 & 132 & 136 & 114 & 184 \\
\hline
\end{tabular}

a Analyses of altered samples by U'nis ersity of Birmingham, England (Wood et al, this volume)

b Whole rock microprobe analyses of "unaltered" separates (see text). Accuracy and precision data in Appendix. Analyses represent volatile free compositions.

Microprobe analyses of interstitial glass in pillow rinds.

d Numbers represent IPOD notation of leg-site-core-ection (m), e.g., 60-458.28.1, 140-142.

${ }^{\mathrm{c}}$ Interpolated from University of Birmingham data for samples from same core and section. 
Samples from Petrographic Units I through III show only minor variations in igneous chemistry but display a wide range of textures. Examples of the textural differences are shown in Plates 1 and 2.

Data for the concentrations of $\mathrm{Y}, \mathrm{Zr}, \mathrm{Cr}$, and $\mathrm{Ni}$ in samples (see Wood et al., this volume) from this hole are plotted in Figure 5. These elements appear to be "immobile" during low temperature processes (Smith and Smith, 1976) and are therefore of considerable significance with regard to the definition of original chemical trends. In terms of overall trends, $\mathrm{Ni}$ and $\mathrm{Cr}$ decrease and $\mathrm{Y}$ and $\mathrm{Zr}$ increase downward in the section. Because $\mathrm{Y}$ and $\mathrm{Zr}$ are essentially incompatible elements $(\overline{\mathrm{D}}<0.2)$ and $\mathrm{Ni}$ and $\mathrm{Cr}$ are compatible elements $(\overline{\mathrm{D}}>2.0)$ in this system, these trends also indicate a general decrease in differentiation index upward. This is opposite to the trend expected for the differentiation and episodic eruption of a single batch of magma and therefore implies the existence of multiple magma batches. Some idea of the number and complexity of magma batches can be derived by recognition of the fact that, during differentiation of this type of magma, a residual liquid will have higher $\mathrm{Zr}$ and $\mathrm{Y}$ and lower $\mathrm{Ni}$ and $\mathrm{Cr}$ abundances than its parent. If we assume the analyses plotted in Figure 5 represent liquid compositions with the youngest at the top and the oldest at the bottom, a line connecting two cogenetic magmas (residual and parent) will have a negative slope for $\mathrm{Ni}$ and $\mathrm{Cr}$ versus depth and a positive slope for $\mathrm{Y}$ and $\mathrm{Zr}$. Inspection of the figure indicates this constraint is not of ten met, suggesting either that many individual batches of magma were produced in the source region and erupted or that the magma chamber feeding the eruptions was periodically replenished.

The distinctions between magma types erupted in this hole are particularly well displayed in a $\mathrm{Zr}$ versus $\mathrm{TiO}_{2}$ diagram. Because both of these elements have similarly low bulk distribution coefficients in this system, their ratio closely reflects the ratio of their parent materials. As shown in Figure 6, samples from C.U. III have higher $\mathrm{TiO}_{2} / \mathrm{Zr}$ ratios than C.U. I and II samples. Combined with the other major element and trace element data already discussed, these data suggest the existence of two magma types in Hole 458; the first type, represented by C.U. III, may be classified as an arc tholeiite series magma. The second type represented by C.U. I and II, is characterized by enrichment of refractory elements and depletion of LIL elements relative to other andesites. Because this type includes boninite-like rocks, it is tentatively called a "boninite series" magma (Meijer, 1980).

The low $\mathrm{TiO}_{2}$ and $\mathrm{Zr}$ contents and the low $\mathrm{TiO}_{2} / \mathrm{Zr}$ ratios of the C.U. I and II samples are distinctive among igneous rock series in general and suggest derivation from very depleted source materials (Coish and Church, 1979; Meijer, 1980). That C.U. II samples have higher LIL element abundances than samples from C.U. I, combined with the fact that samples from both units have similar LIL element ratios, suggests that C.U. II samples could have differentiated from parent magmas similar in composition to the C.U. I samples. This is not true for the C.U. III samples. Note, however, that C.U. II is older than C.U. I and thus cannot have differentiated directly from the C.U. I magmas.
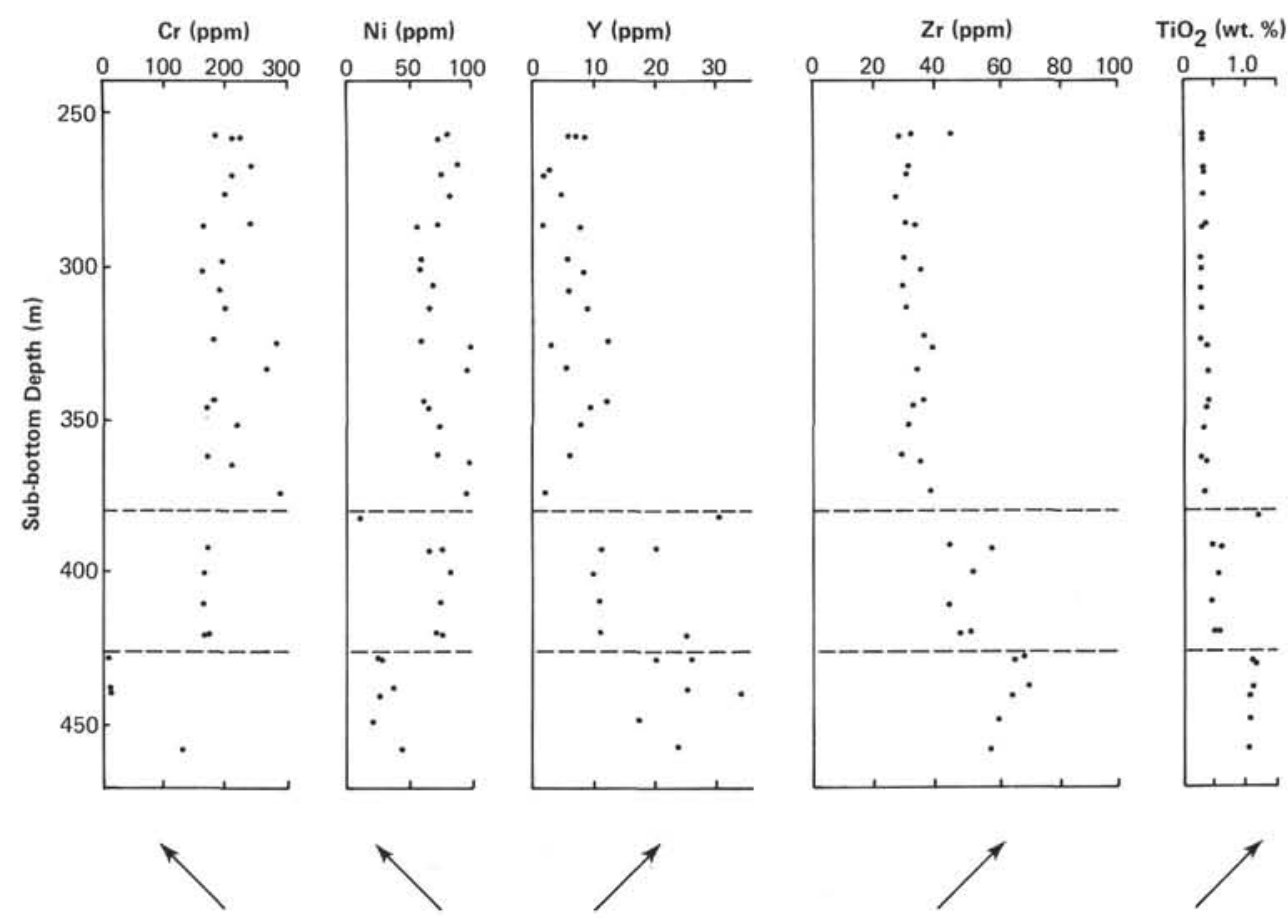

Figure 5. "Immobile" trace elements vs. depth for Hole 458 samples. Dashed lines separate chemical units. Arrows represent predicted trend of element concentrations with fractional crystallization. Only general trend of arrows is significant. 


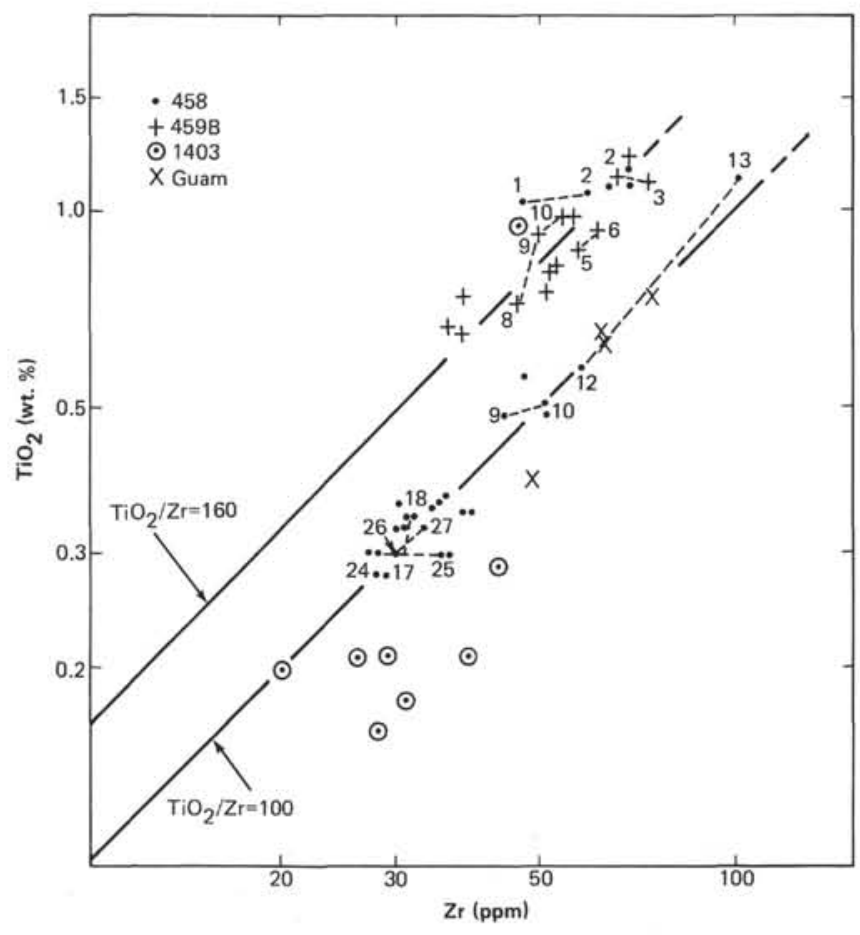

Figure 6. Plot of $\log \mathrm{TiO}_{2}$ vs. $\log \mathrm{Zr}$. Arc tholeiite series lavas have $\mathrm{TiO}_{2} / \mathrm{Zr}$ close to 160 whereas for boninite series lavas this ratio is $\leq 100$. Dashed lines connect analyses of samples that could be cogenetic based on criteria discussed in text. Numbers next to symbols represent relative age sequence of analyses listed in each site chapter, with \#1 being the oldest sample. Only analyses of possible cogenetic samples are numbered. Note that Samples 9 through 13 from Hole 458, C. U. II, could be differentiates of samples from C.U. I (e.g., 17-27) according to this diagram, because fractional crystallization has little effect on $\mathrm{TiO}_{2} / \mathrm{Zr}$ in these magmas.

For those samples which appear to be cogenetic, based on trends in their trace element concentrations, information on the phases that must be removed from one to produce the other by fractional crystallization can be obtained from log plots of the concentration of an incompatible element, such as $\mathrm{Zr}$, with compatible elements, such as $\mathrm{Cr}$ and $\mathrm{Ni}$ (Allegre et al., 1977). For samples from this hole (Fig. 7) the slopes of lines connecting cogenetic pairs yield average $\mathrm{Cr}$ and $\mathrm{Ni}$ bulk distribution coefficients of 2.2 and 2.3 , respectively, for most samples from C.U. I and II and 8.3 and 4.6 for those of C.U. III. These results are puzzling in the sense that the C.U. I and II samples would logically be expected to have higher $\mathrm{Ni}$ and $\mathrm{Cr}$ bulk distribution coefficients than those of C.U. III. Experiments on the liquidus phase relationships in a sample from C.U. I, reported by Kushiro (this volume), indicate that olivine and clinopyroxene are near liquidus phases for this composition up to $13 \mathrm{kbar}$ under hydrous conditions. If these two minerals controlled the fractionation behavior of the C.U. I and II liquids, the bulk distribution coefficients would have values of at least 5 to 10 for $\mathrm{Ni}$ and 3 to 8 for $\mathrm{Cr}$.

Several factors could be responsible for the low values inferred for the $\mathrm{Cr}$ and $\mathrm{Ni}$ distribution coefficients, including the following:

1) The pairs connected by dashed lines in Figure 7 are not all cogenetic even though they display the re- quired age and chemical relationships. As shown in Figure 7, this argument would not explain the more general $\mathrm{L}$-shaped trend among the analyses even without the connecting lines.

2) The values of distribution coefficients are T, P, and composition-dependent and are lower at higher $\mathrm{T}$ and more mafic compositions. For instance, the distribution coefficients for $\mathrm{Ni}$ between olivine and mafic liquids vary greatly with the $\mathrm{MgO}$ content of the liquid (Hart and Davis, 1978). According to the results of Hart and Davis a change in $\mathrm{MgO}$ content of the liquid from 10 to $3 \mathrm{wt} . \%$ can result in a threefold increase in $\mathrm{D}_{\mathrm{Ni}}^{\text {olliq }}$. If the compositional dependence is of similar magnitude for clinopyroxene/liquid and orthopyroxene/liquid, it could explain much of the observed trends. The magnitude of the bulk distribution coefficient for $\mathrm{Cr}$ would also be influenced by the crystallization of a $\mathrm{Cr}$-rich spinel phase. Whether these effects can quantitatively explain the observed trends cannot be adequately evaluated by the available data.

3) Melting versus crystallization effects. Bougault and others (1979) have shown that during partial melting the $\mathrm{Ni}$ and $\mathrm{Cr}$ concentrations in melts produced from mantle materials are buffered by the mantle mineral assemblage (i.e., the melt compositions lie along trends with slightly negative slopes in a diagram such as Fig. 7). This suggests that the low distribution coefficients inferred for the C.U. I and II samples may be an artifact of the derivation of each of the C.U. I and II samples directly from mantle sources and that the higher coefficients for C.U. III samples may represent fractional crystallization at crustal levels. Unfortunately, the calculated concentrations of $\mathrm{Ni}$ and $\mathrm{Cr}$ for melts in equilibrium with mantle assemblages are on the order of 300 to $400 \mathrm{ppm}$ and 800 to $1200 \mathrm{ppm}$, respectively. This is substantially higher than the average values of approximately $75 \mathrm{ppm}$ and $140 \mathrm{ppm}$ observed in the C.U. I and II samples.

The preferred interpretation of the trends in Figure 7 is a combination of factors 2 and 3. That is, C.U. I and II samples probably reflect multiple magma generation events in the mantle followed by fractional crystallization before eruption. Presumably, the C.U. III samples were derived from less $\mathrm{Zr}$-depleted source materials and experienced a higher degree of crystal fractionation than the C.U. I and II samples. Quantitative estimates of the proportions of phases crystallized from these magmas cannot be derived because sufficient data on the compositional dependence of distribution coefficients are not available at present.

\section{HOLE 459B}

The igneous rocks cored in this hole are predominantly fine- to medium-grained $(0.5-0.8 \mathrm{~mm})$ orthopyroxene(?)-clinopyroxene-plagioclase andesites of the arc tholeiite series. The igneous section was subdivided into four units on the basis of shipboard observations (Fig. 8). The occurrence of glassy pillow rinds at several levels in the hole (e.g., Core 65, Section 1 and Core 73, Section 1) suggests the rocks at this site were erupted in a subaqueous environment. Compared to rocks from Hole 458, Hole 459B rocks are generally (1) less vesicu- 

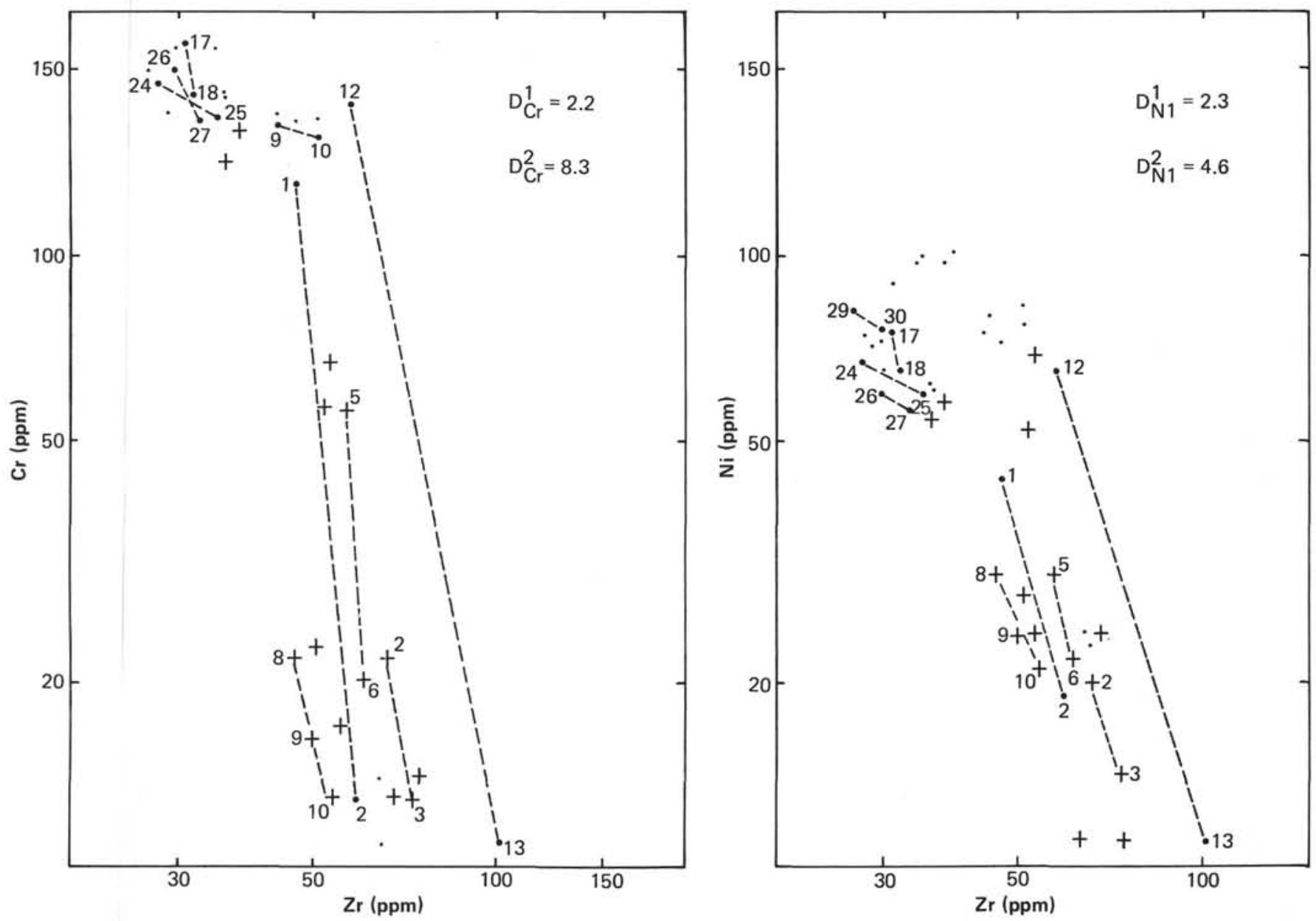

Figure 7. Plot of $\log \mathrm{Cr}$ vs. $\log \mathrm{Zr}$ and $\log \mathrm{Ni}$ vs. $\log \mathrm{Zr}$. Sample numbers and symbols explained in Figure 6. Two trends evident in both plots. Average bulk distribution coefficients derived from the slope of lines connecting possible cogenetic samples within each trend are shown.

lar (5-15\%), (2) more oxidized, (3) more differentiated, (4) coarser grained, (5) more altered, and (6) more extensively fractured.

\section{Mineralogy and Petrology}

\section{Primary Textures}

Like the Hole 458 samples, Hole 459B rocks are texturally similar to typical seafloor basalts and diabases. Most samples studied in thin section show intergranular to subophitic textures with the dominant variable being grain size. The groundmass is generally composed of plagioclase laths, pyroxene granules (predominantly clinopyroxene), $\mathrm{Fe}$-Ti-oxide grains, quartz-feldspar intergrowths, and altered glass. Phenocrysts of plagioclase and clinopyroxene occur in some samples but generally comprise less than $8 \%$ of the total volume. In this respect, the andesites from this hole are distinct from the typically porphyritic arc tholeiites series andesites erupted in subaerial settings. Glassy chill rinds are rare among the rocks recovered. Those that were studied in thin section (Samples 459B-65-1, 34-38 cm and 459B$73-1,80-82 \mathrm{~cm}$ ) consist mostly of clay and zeolite with microlites of primary plagioclase $(5-8 \%)$ and clinopyroxene $(2-3 \%)$.
One of the more distinctive features of the rocks from this hole is the common occurrence of spherulitic to micrographic intergrowths of quartz, feldspar, and Fe-Ti-oxides. The spherulites (Table 6) occur in the finer-grained samples and are essentially identical to those observed in samples from Hole 458 (Plate 2, Figs. $2,3)$. In the coarser-grained samples, micrographic intergrowths of quartz and feldspar occur (Plate 4, Fig. 1). The intimate association of these intergrowths with discrete plagioclase crystals suggests a primary origin as a late stage crystallization product.

\section{Primary Mineralogy}

The primary minerals observed in rocks from this hole include, in order of abundance, plagioclase, clinopyroxene, $\mathrm{Fe}$-Ti-oxides, quartz, and possible unidentified accessory phases (e.g., apatite). Clay-filled pseudomorphs with outlines typical of orthopyroxene occur in many of the samples and suggest this mineral should be included.

Plagioclase is the most abundant crystalline phase in all the samples studied. It varies in habit from spherulitic, to micrographic (Plate 4, Fig. 1), to lath-shaped (Plate 4, Fig. 2), with an average abundance of 30 vol.\%. Compositionally, it varies from approximately 


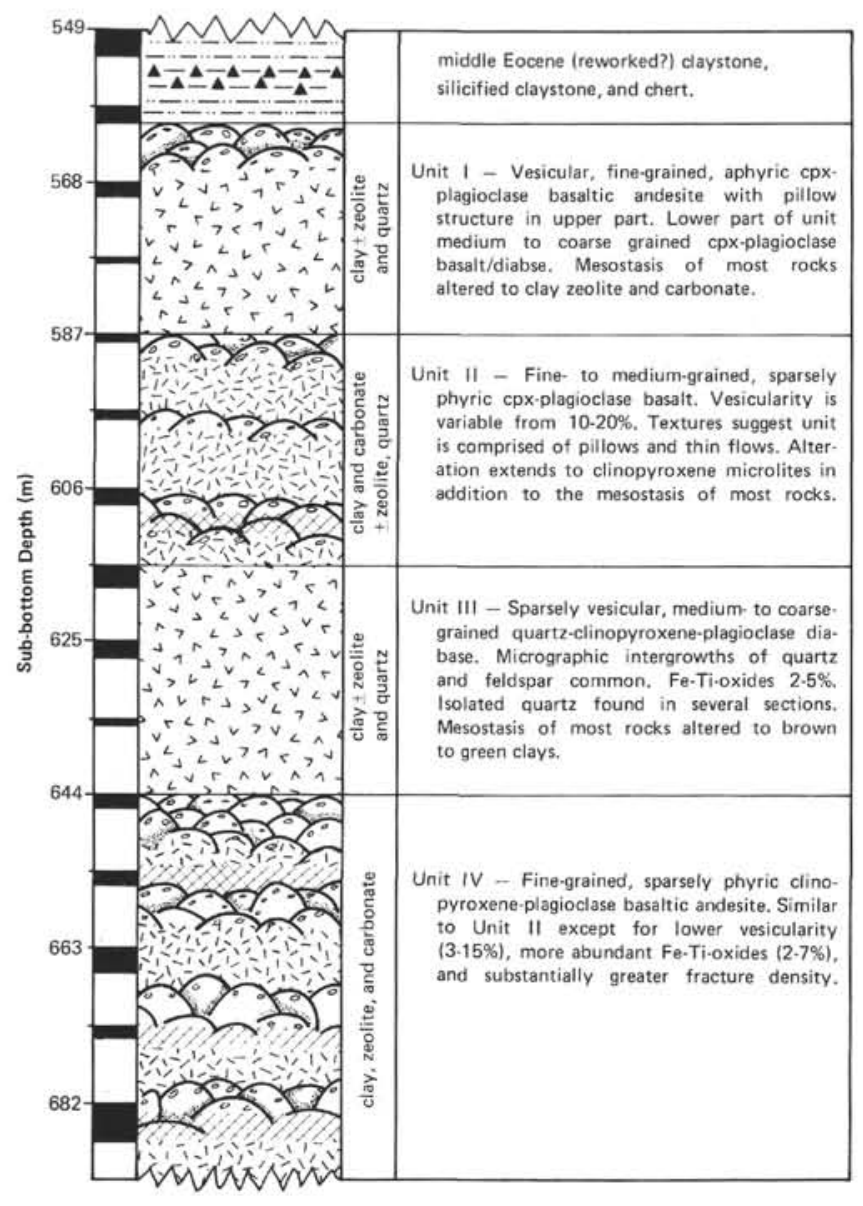

Figure 8. Igneous stratigraphy in Hole 459B. Units I through IV represent petrographic units. Percentage recovery shown as in Figure 1. Cross-hatched horizons represent heavily fractured zones.

$\mathrm{An}_{50}$ in the micrographic intergrowths to $\mathrm{An}_{84}$ for microphenocrysts in the glassy samples. Typical microprobe analyses are given in Table 2 . Zoning is generally restricted to the outer rims of larger crystals. Normal zoning is the most common, although complex zoning was observed in crystals from Unit III.

Clinopyroxene occurs as (1) subhedral to euhedral crystals $(0.3-0.5 \mathrm{~mm})$ subophitically intergrown with plagioclase (Plate 4, Fig. 3), (2) small (0.05-0.1 mm) granules in glassy samples, and (3) as spherulites in quenched samples. Typical compositions are listed in Table 1 and plotted in Figure 2.

An Fe-Ti-oxide phase is invariably present in samples from this hole and usually occurs in two size populations. One size group $(0.03-0.04 \mathrm{~mm})$ displays a blocky habit whereas the other $(\leq 0.01 \mathrm{~mm})$ forms skeletal crystals in the mesostasis. The microprobe analysis listed in Table 5 indicates that the blocky crystals are titanomagnetites.

\section{Secondary Mineralogy}

Secondary minerals identified in samples from this hole include carbonates, zeolites (phillipsite), quartz, cristobalite, tridymite(?), Fe-hydroxides, celadonite, stilpnomelane(?), chlorite/clay(?), and smectite/illite
Table 5. Analyses of accessory primary phases.

\begin{tabular}{|c|c|c|c|c|}
\hline & \multicolumn{3}{|c|}{$\begin{array}{c}\text { Sample } \\
459 \mathrm{~B}-66-3 \text {, } \\
22-26 \mathrm{~cm}\end{array}$} & $\begin{array}{c}\text { Sample } \\
459-68-1 \text {, } \\
18-22 \mathrm{~cm}\end{array}$ \\
\hline $\mathrm{SiO}_{2}$ & 91.67 & 96.81 & 1.98 & 93.94 \\
\hline $\mathrm{TiO}_{2}$ & 0.01 & n.d. & 14.62 & n.d. \\
\hline $\mathrm{Al}_{2} \overline{\mathrm{O}}_{3}$ & 4.32 & 2.99 & 1.26 & 0.32 \\
\hline "FeO" & 2.27 & 3.75 & 69.25 & 3.38 \\
\hline $\mathrm{MnO}$ & n.d. & n.d. & n.d. & n.d. \\
\hline $\mathrm{MgO}$ & 0.03 & 0.11 & 0.44 & 0.04 \\
\hline $\mathrm{CaO}$ & 0.17 & 0.84 & 0.04 & 0.07 \\
\hline $\mathrm{Na}_{2} \mathrm{O}$ & 0.32 & 1.23 & 0.05 & 0.19 \\
\hline $\mathrm{K}_{2} \mathrm{O}$ & 0.09 & 0.15 & 0.21 & 0.07 \\
\hline $\mathrm{P}_{2} \mathrm{O}_{5}$ & n.d. & n.d. & n.d. & n.d. \\
\hline \multirow[t]{2}{*}{ Totala } & 98.88 & 105.89 & 87.84 & 98.01 \\
\hline & \multicolumn{2}{|c|}{$\begin{array}{l}\text { Qtz.-Fe-Ti- } \\
\text { Plag. } \\
\text { spherulite }\end{array}$} & $\begin{array}{l}\mathrm{Fe}-\mathrm{Ti}- \\
\text { oxide }\end{array}$ & $\begin{array}{l}\text { Qtz.-Fe- } \\
\text { Ti-Plag. } \\
\text { spherulite }\end{array}$ \\
\hline
\end{tabular}

series clays. These minerals occur as alteration products of the fine-grained glassy mesostasis and/or primary pyroxene and in veins and vesicles. The degree to which primary minerals have been altered varies erratically down the hole. In general, fine-grained samples with pilotaxitic to intergranular textures have been more thoroughly reconstituted than medium-grained samples with subophitic textures. For samples of a given grain size, however, alteration increases with depth. In finegrained samples from Unit I clinopyroxene is etched but only slightly altered, whereas in similar samples from the bottom of Unit IV clinopyroxene is almost totally altered.

The carbonate phase occurs primarily as a replacement of the fine-grained mesostasis in samples from Unit I. It is also found as a minor alteration product of clinopyroxene. Zeolite occurs locally as a vesicle and vein filling in glassy chill rinds.

Cristobalite and possibly tridymite occur as ubiquitous secondary groundmass minerals. A typical "button" of cristobalite surrounded by secondary clay minerals is shown in Plate 4, Figure 4. Microprobe analyses of two "buttons" are listed in Table 3. The amounts of $\mathrm{Al}_{2} \mathrm{O}_{3}, \mathrm{FeO}$, and $\mathrm{Na}_{2} \mathrm{O}$ in these analyses are typical of secondary cristobalite. Tridymite was tentatively identified in the groundmass of several samples on the basis of crystal form and optic sign.

Sheet silicates including clays, celadonite, sericite, interlayered chlorite/clay, and stilpnomelane(?) occur as alteration products of glass, groundmass constituents, primary mineral phases, and as linings of vugs, vesicles, and veins. In general, the degree of crystallinity of these minerals increases with depth in the hole. A poorly crystalline stilpnomelane-like phase was observed in the lowermost core (Core 73, Section 3). Its identification is based on petrographic characteristics and a microprobe analysis (Table 3). The interlayered chlorite/clay minerals occur primarily in Unit IV, although they also occur as alteration products of orthopyroxene in the other units. Celadonite (Table 3 ) occurs 
as an alteration product of the groundmass from Core 68 downwards. It occurs in the oxidized parts of the groundmass and is generally accompanied by $\mathrm{Fe}$-hydroxides. Because the formation of celadonite requires substantial amounts of $\mathrm{K}_{2} \mathrm{O}$, its presence in abundance implies that these rocks were metasomatically altered.

The clay minerals in these rocks vary in color from aquamarine near the top of the section to chocolate brown near the bottom. A single thin section will often contain two or three differently colored clays. One color occurs as an alteration product of the glassy mesostasis, another is found replacing ferromagnesian minerals, and a third occurs as a lining in vugs and vesicles. These variations presumably reflect a complex alteration history as well as locally variable chemical gradients. A microprobe analysis of vesicles filling clays is listed in Table 3.

\section{Geochemistry}

The primary chemical characteristics of samples from this hole indicate they are andesites of the arc tholeiitic series (Jakes and White, 1972). These characteristics include (1) low $\mathrm{Mg}, \mathrm{Ni}$, and $\mathrm{Cr}$ and relatively high $\mathrm{Fe}$ concentrations; (2) low $\mathrm{K}$ and "intermediate", $\mathrm{Ti}, \mathrm{Y}, \mathrm{Zr}$, and $\mathrm{REE}$ concentrations; and (3) $\mathrm{TiO}_{2} / \mathrm{Zr}$ ratios of 150 to 160 . Primary concentrations and ratios of "mobile" trace elements other than $\mathrm{K}_{2} \mathrm{O}$ have not been obtained because of the effects of secondary alteration.

The extent to which alteration has modified the primary (igneous) compositions of samples from this site is evident in Figure 9, a plot of major element composition versus depth for altered and "unaltered" samples. Unfortunately, glassy pillow rinds which contain the "unaltered" material are rare among the rocks cored in this hole; only two samples were obtained. Microprobe analyses of these two samples, obtained according to the techniques outlined earlier, are very similar to the average arc tholeiite series andesite (Table 4; Jakeŝ and White, 1972).

Comparison of the analyses of altered and unaltered samples from the same core and section (Fig. 9) suggest that $\mathrm{SiO}_{2}$, and to a lesser extent $\mathrm{CaO}$, have been lost; $\mathrm{MgO}, \mathrm{Na}_{2} \mathrm{O}, \mathrm{K}_{2} \mathrm{O}$, and minor " $\mathrm{FeO}$ ' have been gained during the alteration; and $\mathrm{Al}_{2} \mathrm{O}_{3}$ and $\mathrm{TiO}_{2}$ were not significantly changed. A particularly profound example of the effect of secondary alteration is provided by microprobe analyses of interstitial glasses in Sample 459B$65-1,34-38 \mathrm{~cm}$, (Table 6). All the analyses are of pale brown glass showing some etching but no optically distinguishable secondary minerals. The low totals reflect the hydrated condition of these glasses. Measured concentrations of $\mathrm{K}_{2} \mathrm{O}$ vary by at least a factor of 10 among the analyses, the lowest value $(0.33)$ being close to the analysis of "unaltered" material separated from this sample (compare analyses for Sample 459B-65-1, 34-38 $\mathrm{cm}$ in Tables 4 and 5). Combined with the whole-rock data reported in the site chapter and in Figure 9, these data indicate substantial amounts of $\mathrm{K}_{2} \mathrm{O}$, and other "mobile" cations were probably added to the igneous section at this site.

Evidence for primary variations in the chemistry of lavas cored in this hole, based on variations in the " mobile'") elements $\mathrm{Ni}, \mathrm{Cr}, \mathrm{Y}$, and $\mathrm{Zr}$ (Wood et al., this volume), are shown in Figure 10. A distinct trend in chemistry is evident, the lowest cores being the most differentiated. Because these analyses are for sparsely
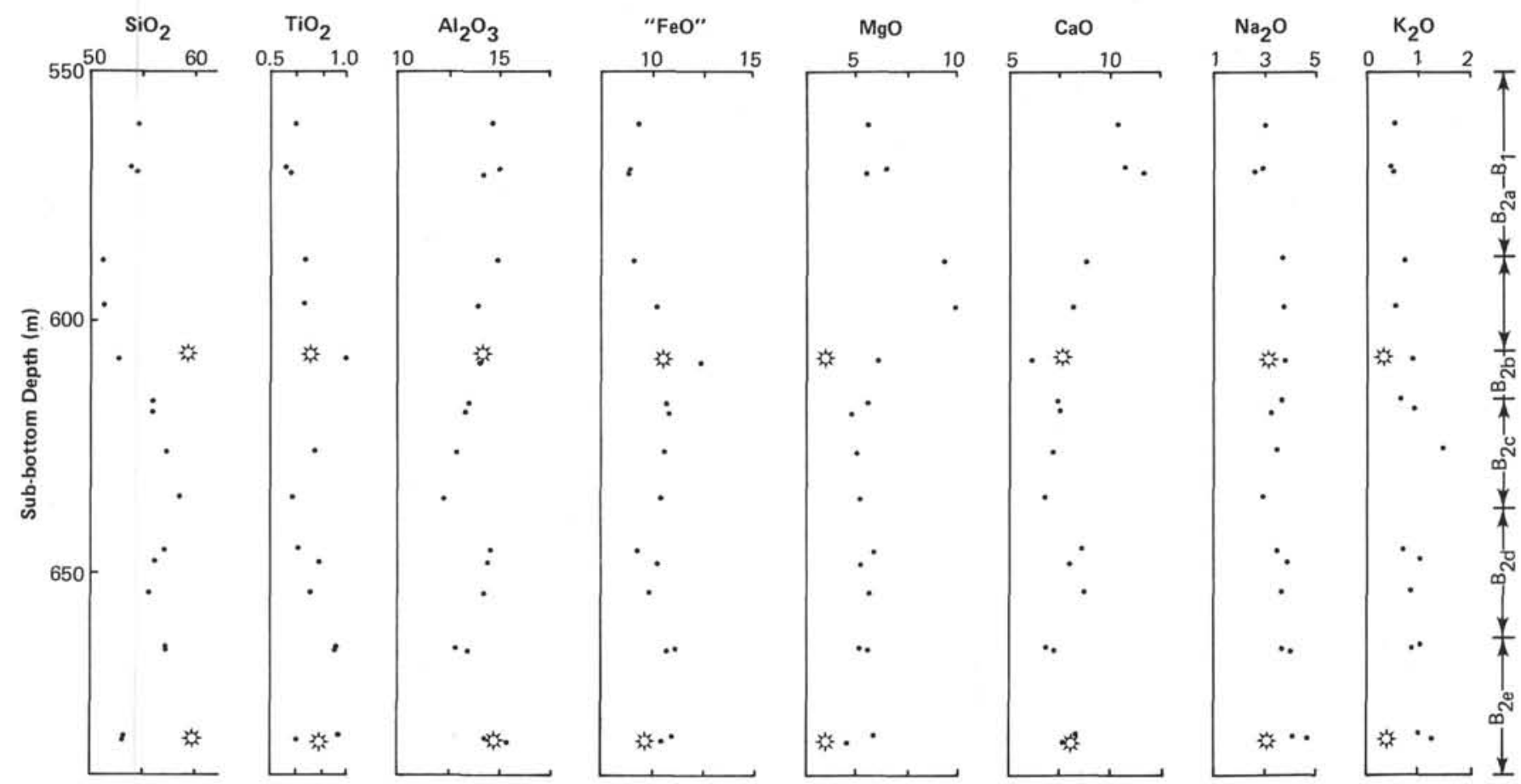

Figure 9. Major elements vs. depth of recovery for samples from Hole 459B. Dots represent analyses of altered samples listed in site chapter. Stars are microprobe-fusion analyses of pillow rind separates. Chemical units as defined in site chapter. All analyses in wt. \%. 
Table 6. Analyses of altered glasses. ${ }^{a}$

\begin{tabular}{lcccrrrrrrr}
\hline \multicolumn{10}{c}{ Sample $459 \mathrm{~B}-65-1,34-38 \mathrm{~cm}$} \\
\hline $\mathrm{SiO}_{2}$ & 46.59 & 59.48 & 50.27 & 53.61 & 51.55 & 48.59 & 51.49 & 49.73 & 53.56 \\
$\mathrm{TiO}_{2}$ & 0.8 & 1.02 & 0.29 & 0.47 & 0.61 & 0.65 & 1.89 & 2.28 & 0.67 \\
$\mathrm{Al}_{2} \mathrm{O}_{3}$ & 10.96 & 13.99 & 12.99 & 15.56 & 8.96 & 9.74 & 11.52 & 10.74 & 10.42 \\
" $\mathrm{FeO}$ " & 8.88 & 11.34 & 10.68 & 5.87 & 17.81 & 14.51 & 14.7 & 14.89 & 16.39 \\
$\mathrm{MnO}$ & n.d. & n.d. & n.d. & 0.19 & 0.16 & n.d. & 0.26 & n.d. & n.d. \\
$\mathrm{MgO}$ & 2.07 & 2.64 & 4.21 & 3.92 & 5.06 & 4.45 & 4.06 & 3.73 & 4.82 \\
$\mathrm{CaO}$ & 5.41 & 6.91 & 1.74 & 1.10 & 2.41 & 1.18 & 1.31 & 1.51 & 1.30 \\
$\mathrm{Na}_{2} \mathrm{O}$ & 2.45 & 3.13 & 0.55 & 0.77 & 0.68 & 0.51 & 0.77 & 0.65 & 0.6 \\
$\mathrm{~K}_{2} \mathrm{O}$ & 0.33 & 0.42 & 2.56 & 3.16 & 3.23 & 3.63 & 3.69 & 3.88 & 4.19 \\
$\mathrm{P}_{2} \mathrm{O} 5$ & n.d. & n.d. & n.d. & 0.02 & 0.02 & n.d. & 0.02 & n.d. & n.d. \\
Totalb & 77.48 & $98.93^{\mathrm{c}}$ & 83.30 & 84.68 & 90.51 & 82.26 & 89.72 & 87.4 & 91.96 \\
\hline
\end{tabular}

a All glasses pale brown with only minor evidence of devitrification.

b Not including volatiles.

c First analysis $\times 1.277$. Compare with Table 4 fusion analysis for Sample 459B-65-1, 34-38 cm.

phyric samples, and these elements are not much affected by low temperature alteration, these trends probably represent trends in magma compositions and indicate that the youngest magmas were the least differentiated. This again precludes a model in which the lavas in this hole derived through progressive crystallization of a single batch of magma and suggests that numerous separate batches of magma underwent shallow-level crystal fractionation and erupted episodically. The consistency of $\mathrm{TiO}_{2} / \mathrm{Zr}$ ratios in the inferred parent magmas does suggest that each batch could have derived from the same or similar source materials.

The similarities between rocks in this hole and samples from C.U. III in Holes 458 are striking. Like the 458 samples, the chemical variations partly reflect shallow level crystal fractionation of the microphenocryst assemblages (see Fig. 7).

\section{HOLES 460, 460A, 461, AND 461A}

Volcanic rocks were recovered as clasts in clayey to conglomeratic sediments cored in these holes. Because they are located near the base of the lower trench slope (23 km for 460 and $460 \mathrm{~A} ; 11 \mathrm{~km}$ for 461 and $461 \mathrm{~A}$ ), the coarse-grained sediments probably include fragments derived from outcrops at various depths along this slope. Whether the rock types and proportions observed in the deposits are representative of the exposures along the trench slope is not known.

\section{Petrography}

Examination of 30 thin sections of volcanic clasts from these holes indicates that many are very similar in texture and mineralogy to the samples cored in Hole 459B. Photomicrographs of typical samples are shown in Plate 5. The common occurrence of $\mathrm{SiO}_{2}$ polymorphs (cristobalite, tridymite, quartz) in the groundmass of these samples makes the correlation with Hole 459B rocks particularly convincing.

In addition to the Hole 459B-like samples, samples with higher-grade metamorphic mineral assemblages were also recovered. Although these were not studied in detail, the available shipboard data indicate that chlorite, amphibole, epidote, and quartz are common constituents. Texturally, most of these samples are of volcanic derivation.

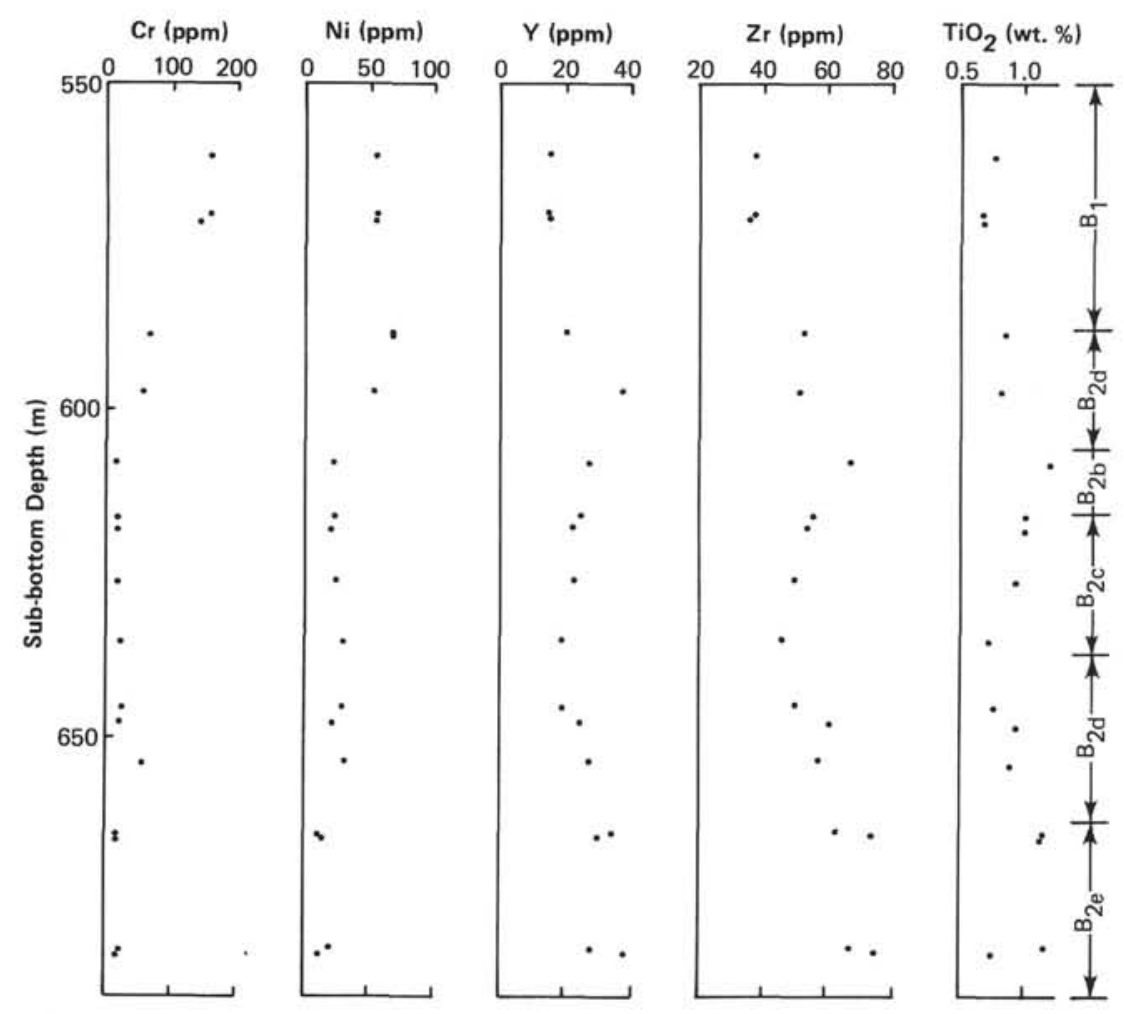

Figure 10. "Immobile" trace elements vs. depth for altered samples from Hole 459B as reported in site chapter. 
A reasonable interpretation of the diversity in metamorphic grade among rocks recovered from deposits along the lower trench slope is that these deposits include samples from deeper stratigraphic levels that those penetrated in Holes 458 and 459B.

In an attempt to discover whether any unusual rock types (e.g., blueschists, eclogite) might be exposed along the lower trench slope, two samples of gravel, each containing several hundred millimeter- to centimeter-sized pebbles were examined under binocular microscope.

One sample $(460 \mathrm{~A}-10, \mathrm{CC})$ contained exclusively volcanic fragments. Most of the fragments were similar to samples from Holes 459B in vesicularity, plagioclase content, color of clay minerals, etc. However, about $10 \%$ of the fragments were light-colored tuffaceous rocks with 10 to $20 \%$ unaltered pyroxene phenocrysts. These could represent either units along the trench slope not penetrated in Hole 459B or be products of young volcanic activity along the Mariana arc trend. There was no evidence of high-pressure, low-temperature (e.g., blueschist facies) metamorphic conditions among the pebbles in this sample.

The second sample $(461 \mathrm{~A}-2, \mathrm{CC})$ contained both volcanic and plutonic fragments. The volcanic fragments were indistinguishable from those in the previous hole, but the plutonic fragments were almost exclusively gabbroic, including two-pyroxene gabbros, uralitic gabbros, and noritic gabbros. Metamorphic minerals observed within these fragments generally reflect high $\mathrm{T}$, low $\mathrm{P}$ greenschist to amphibolite facies conditions. High-pressure, low-temperature assemblages common to the blueschist facies were not observed.

The available chemical data (Table 7) reinforce the close correspondence between the volcanic clasts from the lower trench slope sites and rocks from Hole 459B. Analyses of chips of "fresh" vitreous glass, presumably from pillow rinds, recovered from the gravel samples are presented in Table 7. Some analyses (e.g., Table 7, analyses 9-14) are very close in composition to analyses from Hole 459B, whereas others appear to represent less fractionated liquids of the same series. Note that analyses in Table 7 are for natural glasses whereas those for Hole 459B in Table 4 are for artifically fused glasses.

\section{DISCUSSION}

In most current models of subduction zone complexes, the igneous units are inferred to be fragments of ocean crust \pm mantle. These fragments are thought to be either trapped as a result of the initiation of a new subduction zone (see review by Seely, 1978) or accreted afterward (Dewey and Bird, 1970; Karig and Sharman, 1975), although the details of the structural mechanisms governing these processes have not been worked out. The morphologic diversity of modern fore-arc regions (e.g., Dickinson and Seely, 1979) suggests the possibility of more than one mode of origin.

The rocks recovered from the Leg 60 fore-arc sites provide some basis for interpretations regarding the origin of igneous "basement" in this particular fore-arc complex. The generality of these interpretations clearly remains to be tested by future studies of other complexes.

Rocks with chemical and mineralogic characteristics commonly ascribed to andesites of the arc tholeiite series (Jakeŝ and White, 1972) were recovered from all the Mariana fore-arc sites. In terms of the abundances of REE and other LIL elements, these rocks are similar, for example, to young lavas erupted in the Izu (Masuda, 1968) and Tonga (in Ewart et al., 1977) arcs. The main differences between these groups are in texture (aphyric vs. porphyritic) and environment of eruption (submarine vs. subaerial). This suggests that the Mariana fore-arc tholeiites may be similar to the submarine portions of the younger volcanic arcs.

The rocks from the fore-arc sites at $18^{\circ} \mathrm{N}$ are also chemically and mineralogically similar to rocks of equivalent ages exposed on the islands of Guam and Saipan in the southern Mariana fore-arc region. Here, lavas erupted in both subaerial and submarine environments are exposed (Cloud et al., 1956; Tracey et al., 1963). Because hypersthene-augite andesites are common in the volcanic sequences on both islands, they probably originated in a volcanic arc environment. Hyperstheneaugite andesites have not been reported from other oceanic environments (Macdonald, 1960).

If a volcanic arc origin is accepted for the Mariana fore-arc tholeiites, the question arises as to why these lavas are currently exposed in such close proximity to the trench $(\leq 50 \mathrm{~km})$. Answers to this question are likely to involve both petrologic and tectonic factors. Petrologic factors might include the likelihood that these lavas were erupted onto very young and therefore very thin oceanic lithosphere of the West Philippine Sea as discussed in Meijer (in press). Tectonic factors include

Table 7. Analyses of glasses ${ }^{\mathrm{a}}$ in Holes $460 \mathrm{~A}$ and $461 \mathrm{~A}$.

\begin{tabular}{|c|c|c|c|c|c|c|c|c|c|c|c|c|c|c|c|c|c|c|c|c|}
\hline \multirow[b]{2}{*}{ Analysis } & \multicolumn{6}{|c|}{ Hole $460 \mathrm{~A}$} & \multicolumn{14}{|c|}{ Hole 461A } \\
\hline & 1 & 2 & 3 & 4 & 5 & 6 & 1 & 2 & 3 & 4 & 5 & 6 & 7 & 8 & 9 & 10 & 11 & 12 & 13 & 14 \\
\hline $\mathrm{SiO}_{2}$ & 56.99 & 56.86 & 55.89 & 57.03 & 57.50 & 56.56 & 54.73 & 55.14 & 55.27 & 55.21 & 55.34 & 56.69 & 56.54 & 57.10 & 59.04 & 58.99 & 59.87 & 60.26 & 60.26 & 60.49 \\
\hline $\mathrm{TiO}^{-}$ & 0.77 & 0.84 & 0.79 & 0.77 & 0.80 & 0.83 & 0.65 & 0.56 & 0.55 & 0.59 & 0.58 & 0.71 & 0.81 & 0.82 & 0.77 & 0.82 & 0.92 & 0.91 & 0.74 & 0.82 \\
\hline $\mathrm{Al}_{2} \mathrm{O}_{3}$ & 14.69 & 14.16 & 14.55 & 14.26 & 14.56 & 14.60 & 15.30 & 15.30 & 15.49 & 15.17 & 15.38 & 14.54 & 14.47 & 14.28 & 14.43 & 14.40 & 14.21 & 14.18 & 14.04 & 14.05 \\
\hline "FeO" & 11.14 & 11.35 & 11.01 & 11.15 & 11.14 & 11.19 & 9.60 & 9.67 & 9.60 & 9.62 & 9.83 & 11.04 & 11.02 & 11.18 & 10.62 & 10.42 & 10.83 & 10.46 & 10.00 & 9.72 \\
\hline $\mathrm{MgO}$ & 3.43 & 3.08 & 3.42 & 3.20 & 3.07 & 3.33 & 4.73 & 4.72 & 4.63 & 4.60 & 4.58 & 3.39 & 3.18 & 2.89 & 2.55 & 2.45 & 2.16 & 2.17 & 2.05 & 1.95 \\
\hline $\mathrm{CaO}$ & 8.00 & 7.87 & 8.01 & 7.95 & 7.61 & 7.95 & 9.48 & 9.05 & 9.27 & 9.24 & 9.30 & 7.93 & 7.70 & 7.54 & 7.03 & 7.03 & 6.77 & 6.97 & 6.27 & 6.22 \\
\hline $\mathrm{Na}_{2} \mathrm{O}$ & 2.95 & 2.95 & 2.91 & 2.99 & 2.97 & 2.94 & 2.49 & 2.35 & 2.49 & 2.39 & 2.46 & 2.81 & 2.89 & 3.04 & 3.01 & 3.08 & 2.92 & 3.19 & 3.28 & 2.86 \\
\hline $\mathrm{K}_{2} \mathrm{O}$ & 0.29 & 0.30 & 0.30 & 0.31 & 0.31 & 0.31 & 0.24 & 0.24 & 0.26 & 0.25 & 0.25 & 0.30 & 0.30 & 0.31 & 0.34 & 0.35 & 0.33 & 0.35 & 0.37 & 0.37 \\
\hline Total $^{\mathrm{b}}$ & 98.24 & 97.41 & 96.88 & 97.66 & 97.96 & 97.71 & 97.21 & 97.04 & 97.55 & 97.07 & 97.72 & 97.42 & 96.91 & 97.17 & 97.80 & 97.53 & 98.02 & 98.48 & 97.00 & 96.47 \\
\hline
\end{tabular}

Note: Each analysis represents a separate fragment. Fragments $90-100 \%$ glass.

a There are natural glasses most likely from pillow rind fragments.

b Low totals reflect varying volatile contents of the glasses. 
tectonic erosion of the lower trench slope by subduction and rifting of the fore-arc region parallel to the trench (Karig, 1974). Whatever the cause, the phenomenon is clearly not restricted to the Mariana fore-arc region, because similar geometries are found in the New Hebrides arc (Esperitu Santo and Malekula: Colley and Warden, 1974), the Tonga arc (Eua: Ewart and Bryan, 1972), the Bonin arc (Tsuya, 1937), and other arc systems.

The tectonic and petrologic significance of the boninite series lavas recovered from Hole 458 is more difficult to ascertain because, to our knowledge, lavas of this type have not been recognized among the products of recent (Pleistocene-Holocene) volcanism. Their chemical characteristics apparently reflect derivation from very depleted ultramafic source materials (Coish and Church, 1979; Meijer, 1980). Because such source materials are likely to be very refractory, it would require special conditions to cause them partially to melt. Laboratory experiments (Green, 1976) suggest that these conditions include high $\mathrm{H}_{2} \mathrm{O}$ contents and relatively low pressures $(10-20 \mathrm{kbar})$ at 1100 to $1200^{\circ} \mathrm{C}$.

The primary abundance of $\mathrm{H}_{2} \mathrm{O}$ is characteristically very low in oceanic lavas (Moore, 1970; Delaney et al., 1978; Harris, 1979a) but can be quite high in volcanic arc lavas (Anderson, 1975; Harris, 1979b). This dichotomy is logically ascribed to the influence of the hydrated ocean crust subducted beneath volcanic arcs (Delany and Helgeson, 1978). Dehydration of this crust should release $\mathrm{H}_{2} \mathrm{O}$ and other volatiles into the mantle overlying the crust, and these presumably could cause melting of the mantle to produce arc magmatism.

The boninite series magmas would appear therefore, to be genetically related to subduction zones as well. A multistage melting process of mantle overlying a subduction zone could produce the arc tholeiite series during the early stages of melting and the boninite series in later stages as the source material is continuously depleted in LIL elements (Meijer, 1980). Each progressive stage presumably would require a greater amount of water to cause a given amount of partial melting.

On the basis of paleogeographic reconstructions, it appears the $\mathrm{P}, \mathrm{T}, \mathrm{f}_{\mathrm{H}_{2} \mathrm{O}}$ conditions required for the production of boninitic magmas may well have been attained along the late Eocene-Oligocene Palau-Kyushu Ridge from which the Mariana frontal arc was split in the Oligocene time (32 Ma; Sutter and Snee, 1978). If subduction was initiated beneath the ridge in the late Eocene, as suggested by the age of the oldest arc rocks exposed in the Mariana fore-arc region (Meijer, 1980), it would have occurred beneath very young (0-8 Ma) and therefore relatively hot West Philippine Sea lithosphere. The addition of $\mathrm{H}_{2} \mathrm{O}$ to this lithosphere from the subducted ocean crust would probably have caused melting at relatively shallow depths as required by the experimental data (Green, 1976). The relative rarity of boninitic rocks might therefore, be ascribed to the unusual thermal conditions required for their production.

On the basis of the data on secondary mineral assemblages discussed earlier, it appears that the igneous crust of the Mariana fore-arc region at $18^{\circ} \mathrm{N}$ has undergone a relatively simple low-grade alteration of the type generally found in seafloor basalts (e.g, Bass, 1976). This, combined with the other data discussed, leads to the conclusion that the Mariana fore-arc crust was formed in an arc environment and has remained near its present stratigraphic level since formation. No evidence for accreted slabs of Pacific Plate crust or high P, low T metamorphism has been uncovered.

\section{CONCLUSIONS}

In terms of physical form (reflecting eruptive mode), petrographic textures, and extent of alteration, the volcanic rocks recovered from the fore-arc sites are similar to volcanic rocks recovered from the major ocean basins. This similarity does not extend to the mineralogy and chemistry. The fore-arc samples consist mineralogically of two-pyroxene andesites and chemically of arc tholeiite series andesites and bronzite andesites of what might be called a "boninite series." This divergence between physical characteristics on the one hand and mineralogical and chemical characteristics on the other will complicate recognition of the fore-arc rock types in older orogenic belts, particularly in view of the altered condition of volcanic sequences in most of these belts.

On the basis of chemical and mineralogic characteristics, their correlation with arc sequences on Guam and Saipan, the low grade of alteration they have experienced, and their youth relative to adjacent Pacific lithosphere, we conclude that the fore-arc rocks at $18^{\circ} \mathrm{N}$ were formed in a subduction zone environment. If valid, this conclusion implies arc-related lavas were erupted very close (50-100 km) to an Eocene-Oligocene trench. It follows that fore-arc basement rocks may, at least in some instances, have no direct relation to the oceanic lithosphere subducted beneath an arc. Because the basement at $18^{\circ} \mathrm{N}$ now represents one of the most thoroughly studied in situ fore-arc basement terrains, other modes of origin postulated for these terrains will require more detailed analysis. In particular, the common assumption that most ophiolites represent fragments of oceanic lithosphere accreted or trapped during subduction may require modification.

In terms of origins, the volcanic rock sequences in Holes 458 and 459B reflect the eruption of progressively more primitive (i.e., less differentiated) magmas through time. In both holes, andesites of the arc tholeiite series represent the oldest rocks recovered. These were followed in Hole 458 by the eruption of a second, more primitive series, not genetically related to the first by simple crystal fractionation. Both series could have been derived from source materials in the mantle overlying the Eocene-Oligocene subduction zone. The main requirements for their production at shallow depths are an adequate supply of $\mathrm{H}_{2} \mathrm{O}$ and a high geothermal gradient in the source mantle. Paleogeographic reconstructions suggest both conditions could have been satisfied within the Eocene-Oligocene Palau-Kyushu-Mariana Ridge subduction zone above which the lavas were erupted.

\section{ACKNOWLEDGMENTS}

We would like to express our gratitude to the Deep Sea Drilling Project and its parent organization the National Science Foundation for providing the Leg 60 samples. We thank John Tarney and his co- 
workers for providing chemical analyses to the shipboard scientific party. Paul Damon and John W. Anthony kindly reviewed the manuscript and Arthur Roe performed several X-ray diffraction analyses. Our work was carried out as part of the Southeast Asia Tectonics and Research Project (S.E.A.T.A.R.) funded by the Office of the International Decade of Ocean Exploration at the National Science Foundation. The University of Arizona cleared the way for one of us (A.M.) to participate in the Leg 60 cruise, and this assistance is gratefully acknowledged. Finally, we thank Sandra L. Meijer for her patience in the typing and completion of the manuscript.

\section{REFERENCES}

Abbey, S., 1975. Studies in "standard samples" of silicate rocks and minerals. Part 4: 1974 edition of "usable" values. Can. Geol. Surv. Pap., 74-41.

Albee, A. L., and Ray, L., 1970. Correction factors for electron probe microanalysis of silicates, oxides, carbonates, phosphates, and sulfates. Anal. Chem., 42:1409-1414.

Allegre, C. J., Trueil, M., Minster, J. F., et al., 1977. Systematic use of trace element in igneous process. Part I: Fractional crystallization processes in volcanic suites. Contrib. Mineral. Petrol., $60: 57-75$.

Anonymous, 1977. Initial report of the geological study of oceanic crust of the Philippine sea floor. Ofioliti, 2:137-168.

Bass, M. N., 1976. Secondary minerals in oceanic basalt, with special reference to Leg 34, Deep Sea Drilling Project. In Barker, P. F., Dalziel, I. W. D., et. al., Init. Repts. DSDP, 36: Washington (U.S. Govt. Printing Office), 393-432.

Bass, M. N.,, Moberly, R., Rhodes, J. M., et al., 1973. Volcanic rocks cored in the central Pacific, Leg 17, Deep Sea Drilling Project. In Winterer, E. L., Ewing, J. I., et al., Init. Repts. DSDP, 17: Washington (U.S. Govt. Printing Office), 429-503.

Bence, A. E., and Albee, A. L., 1968. Empirical correction factors for the electron microanalysis of silicates and oxides. J. Geol., 76: 382-403.

Bougault, H., Cambon, P., Corre, O., et al., 1979. Evidence for variability of magmatic processes and upper mantle heterogeneity in the axial region of the Mid-Atlantic Ridge near $22^{\circ}$ and $36^{\circ} \mathrm{N}$. Tectonophysics, 55:1-34.

Brown, R. W., 1976. A sample fusion technique for whole rock analysis with the electronic microprobe. Geochim. Cosmochim. Acta, $41: 435-438$.

Cameron, W. E., Nisbet, E. G., and Dietrich, V. J., 1979. Boninites, komatiites and ophiolitic basalts. Nature, 280:550-553.

Cloud, P. E., Jr., Schmidt, R. G., and Burke, H. W., 1956. Geology of Saipan, Mariana Islands. U.S. Geol. Surv. Prof. Pap., 280-A.

Coish, R. A., and Church, W. R., 1979. Igneous geochemistry of mafic rocks in the Betts Cove Ophiolite, Newfoundland. Contrib. Mineral. Petrol., 70:29-39.

Colley, H., and Warden, A. J., 1974. Petrology of the New Hebrides. Geol. Soc. Am. Bull., 85:1635-1646.

Dallwitz, W. B., Green, D. H., and Thompson, J. E., 1966. Clinoenstatite in a volcanic rock from the Cape Vogel area, Papua. $J$. Petrol., 7:375-403.

Delaney, J. R., Meunow, D., and Graham, D. G., 1978. Abundance and distribution of water, carbon and sulfur in the glassy rims of submarine pillow basalts, Geochim. Cosmochim. Acta, 42: 581-594

Delany, J. M., and Helgeson, H. C., 1978. Calculation of the thermodynamic consequences of dehydration in subducting oceanic crust to $100 \mathrm{kbar}$ and $>800^{\circ} \mathrm{C}$. Am. J. Sci., 278:638-686.

Dewey, J. F., and Bird, J. M., 1970. Mountain belts and the new global tectonics. J. Geophys. Res., 75:2625-2647.

Dickinson, W. R., and Seely, D. R., 1979. Structure and stratigraphy of forearc regions. Am. Assoc. Petrol. Geol. Bull., 63:2-31.

Dietrich, V., Emmerman, R., Oberhansli, R., et al., 1978. Geochemistry of basaltic and gabbroic rocks from the West Mariana Basin and the Mariana Trench. Earth Planet. Sci. Lett., 39:127-144.

Ewart, A., Brothers, R. N., and Mateen, A., 1977. An outline of the geology and geochemistry, and the possible petrogenetic evolution of the volcanic rocks of the Tonga-Kermadec-New Zealand island arc. J. Volcan. Geotherm. Res., 2:205-250.

Ewart, A., and Bryan, W. B., 1972. The petrology and geochemistry of the igneous rocks from Eua, Tongan Islands. Geol. Soc. Am. Bull., 83:3281-3298.
Green, D. H., 1976. Experimental testing of "equilibrium" partial melting of peridotite under water-saturated, high-pressure conditions. Can. Mineral., 14:255-268.

Harris, D. M., 1979a. Geobarometry and geothermometry of individual crystals using $\mathrm{H}_{2} \mathrm{O}, \mathrm{CO}_{2}, \mathrm{~S}$, and major element concentrations in silicate melt inclusions: 2. The 1959 eruption of Kilauea Volcano, Hawaii. Geol. Soc. Am. Abstracts with Programs, 11: 439 .

1979b. Pre-eruption variations of $\mathrm{H}_{2} \mathrm{O}, \mathrm{S}$, and $\mathrm{Cl}$ in a subduction zone basalt. EOS, 60:968.

Hart, S. R., and Davis, K. E., 1978. Nickel partitioning between olivine and silica melt. Earth Planet. Sci. Lett., 40:203-219.

Jakes, P., and White, A. J. R., 1972. Major and trace element abundances in volcanic rocks of orogenic areas. Geol. Soc. Am. Bull., 83:29-40.

Johanssen, A., 1939. A Descriptive Petrography of the Igneous Rocks (Vol. 1): Chicago (University of Chicago Press).

Karig, D. E., 1974. Tectonic erosion at trenches. Earth Planet. Sci. Lett., 21:209-212.

Karig, D. E., and Sharman, G. F., III, 1975. Subduction and accretion in trenches. Geol. Soc. Am. Bull., 86:377-389.

Kuroda, M., and Shiraki, K., 1975. Boninite and related rocks of Chichi-jima, Bonin Islands, Japan. Rep. Fac. Sci. Shizuoka Univ., $10: 145-155$.

Macdonald, G. A., 1960. Dissimilarity of continental and oceanic rock types. J. Petrol., 1:172-177.

Masuda, A., 1968. Geochemistry of lanthanides in basalts of central Japan. Earth Planet. Sci. Lett., 4:284-292.

Meijer, A., 1980. Primitive arc volcanism and a boninite series. In Hayes, D. (Ed.), The Tectonic and Geophysical Evolution of Southeast Asian Seas and Islands: Geophysical Monograph 23: Washington (American Geophysical Union), 269-282.

Moore, J. G., 1970. Water content of basalt erupted on the ocean floor. Contrib. Mineral. Petrol., 28:272-279.

Scheidegger, K. F., and Stakes, D. S., 1977. Mineralogy, chemistry and crystallization sequence of clay minerals and altered tholeiitic basalts from the Peru Trench. Earth Planet. Sci. Lett., 36(3): 413-422.

Schmidt, R. G., 1957. Petrology of the volcanic rocks. Geology of Saipan, Mariana Islands (Pt. 2): U.S. Geol. Surv. Prof. Pap. $280-B, 127-175$.

Seely, D. R., 1978. The evolution of structural highs bordering major forearc basins. Am. Assoc. Petrol. Geol. Mem., 29:245-260.

Sharaskin, A. Ya., Dobretsov, N. L., and Soboler, N. V., in press. Marianites: The clinoenstatite bearing pillow lavas associated with ophiolite assemblage of the Mariana Trench. Proc. Int. Ophiolite Symp. Cyprus.

Smith, R. E., and Smith, S. E., 1976. Comments on the use of Ti, Zr, $\mathrm{Y}, \mathrm{Sr}, \mathrm{K}, \mathrm{P}$, and $\mathrm{Nb}$ in classification of basaltic magmas. Earth Planet. Sci. Lett., 32:114-120.

Sutter, J. F., and Snee, L. W., 1978. K/Ar and ${ }^{40} \mathrm{Ar} /{ }^{39} \mathrm{Ar}$ dating of basaltic rocks from DSDP Leg 59. Eos, 59:1179.

Tracey, J. I., Schlanger, S. O., Stark, J. T., et al., 1963. General geology of Guam. U.S. Geol. Surv. Prof. Pap. 403-A.

Tsuya, H., 1937. On the volcanism of the Huzi volcanic zone with special reference to the geology and petrology of Izu and the southern islands. Bull. Earthq. Res. Inst., 15:215-357.

\section{APPENDIX \\ Analytical Procedures}

Phenocryst and bulk rock major element compositions were determined using an ARL-SEMQ electronic microprobe. The accelerating voltage was $15 \mathrm{kv}$ and the sample current (on benitoite) 20 to 30 nanoamperes. Bence-Albee corrections (Bence and Albee, 1968; Albee and Ray, 1970) were applied to all analyses.

Phenocryst and glass analyses were performed on polished thin sections. A beam size of $30 \mu \mathrm{m}$ was used for analyses of glass and large phenocrysts and $5 \mu \mathrm{m}$ for microphenocrysts. A natural basaltic glass from the Juan de Fuca Ridge (United States National Museum $111240 / 52$ ) was used as a calibration sample for all elements. Precision was monitored by analyzing the Juan de Fuca Ridge glass at the beginning and end of each day and by re-analyzing selected phenocrysts on successive days. Comparison of values, using the equation (1st value -2 nd value/1st value) $\times 100$, showed that analyses were 
generally within a few percent. Accuracy was monitored by analyzing minerals of known chemical composition, usually Kakanu hornblende, after calibration during each microprobe session. The results of typical analyses are presented in Table 1.

The hand-picked chill rind separates were analyzed in the following manner. Samples were crushed and $20 \mathrm{mg}$ of the powder fused in a Mo strip furnace at $1750^{\circ} \mathrm{C}$ under $\mathrm{Ar}$ at atmospheric pressure (see Brown, 1977, for a discussion of fusion techniques). The fused glasses were then mounted and analyzed using a $30-\mu \mathrm{m}$ beam. Two to six analyses of each fused sample were average to minimize the effects of compositional heterogeneities in the glasses. The Juan de Fuca Ridge glass was used as a calibration sample for all elements except potassium and titanium, for which the Kakanui hornblende (USNM 143965) was used. Accuracy was monitored by fusing and analyzing USGS rock standards BCR-1 and W- 1 . The values obtained for all the major elements are usually within $5 \%$ of the reported "dry" values (Table 1). There has been some debate over whether the fusion technique and analysis of glasses using the electron microprobe cause volatization and loss of some elements, particularly sodium. Although we did observe lower sodium values in the fused USGS rock powders than are reported, the problem was not substantial, as is indicated by the data reported in Table 7.

Table 1. Estimates of accuracy for mineral and fused glass analyses of standards.

\begin{tabular}{|c|c|c|c|c|c|c|c|c|c|c|c|c|c|c|}
\hline & $\begin{array}{c}\text { Kakanui } \\
\text { hornblende } \\
\text { 12-18-79 }\end{array}$ & $\Delta \%_{0}^{\mathrm{a}}$ & $\begin{array}{c}\text { Kakanui } \\
\text { hornblende } \\
11-29-79\end{array}$ & $\Delta \%$ & $\begin{array}{c}\text { Kakanui } \\
\text { hornblende } \\
\text { av. } \Delta \%_{0} b\end{array}$ & $\begin{array}{l}\text { Kakanui } \\
\text { hornblende } \\
\text { Reported }\end{array}$ & $\begin{array}{l}\text { BCR-1 } \\
8-30-79\end{array}$ & $\Delta \%$ & $\begin{array}{l}\text { BCR-1 } \\
\text { av. } \Delta \% \text { d }\end{array}$ & $\begin{array}{c}\text { BCR-1 } \\
\text { Reported }^{\text {e }}\end{array}$ & $\begin{array}{c}\text { W-1 } \\
10-9-79\end{array}$ & $\Delta \%$ & $\begin{array}{l}\text { W-1 } \\
\text { av. } \Delta \% \mathrm{f}\end{array}$ & $\begin{array}{c}\text { W-1 } \\
\text { Reported }^{\text {e }}\end{array}$ \\
\hline $\mathrm{SiO}_{2}$ & 41.27 & 2.23 & 41.02 & 1.61 & 0.94 & 40.37 & 54.62 & 1.27 & 1.15 & 55.32 & 52.75 & 0.57 & 1.09 & 53.05 \\
\hline $\mathrm{TiO}_{2}$ & 4.48 & 5.09 & 4.63 & 1.91 & 3.85 & 4.72 & 2.23 & 0.45 & 4.58 & 2.24 & 0.93 & 13.89 & 10.95 & 1.08 \\
\hline $\mathrm{Al}_{2} \mathrm{O}_{3}$ & 15.03 & 0.87 & 15.06 & 1.07 & 2.03 & 14.9 & 14.21 & 2.97 & 4.20 & 13.8 & 16.13 & 7.82 & 7.02 & 14.96 \\
\hline $\mathrm{FeO}_{\mathrm{t}}$ & 10.51 & 3.76 & 10.68 & 2.2 & 3.73 & 10.92 & $! 2.19$ & 0.73 & 4.60 & 12.18 & 10.27 & $2: 19$ & 2.92 & 10.05 \\
\hline $\mathrm{MnO}$ & n.d. & - & n.d. & - & - & 0.09 & n.d. & - & - & - & n.d. & - & - & - \\
\hline $\mathrm{MgO}$ & 12.72 & 0.63 & 12.31 & 3.83 & 4.7 & 12.8 & 3.37 & 4.26 & 8.29 & 3.52 & 6.71 & 0.6 & 5.98 & 6.67 \\
\hline $\mathrm{CaO}$ & 10.14 & 1.55 & 10.32 & 0.19 & 0.76 & 10.3 & 7.01 & 0.43 & 3.67 & 7.04 & 11.01 & 0.36 & 1.44 & 11.05 \\
\hline $\mathrm{Na}_{2} \mathrm{O}$ & 2.71 & 4.23 & 2.66 & 2.31 & 2.97 & 2.6 & 3.11 & 6.33 & 5.67 & 3.32 & 2.29 & 6.02 & 7.82 & 2.16 \\
\hline $\mathrm{K}_{2} \mathrm{O}$ & 2.0 & 2.44 & 1.98 & 3.42 & 4.39 & 2.05 & 1.53 & 9.47 & 4.76 & 1.69 & 0.61 & 4.69 & 5.29 & 0.64 \\
\hline $\mathrm{P}_{2} \mathrm{O}_{5}$ & n.d. & - & n.d. & - & - & n.d. & n.d. & - & - & - & n.d. & - & - & - \\
\hline Total & 98.87 & - & 98.66 & - & - & 99.08 & 98.27 & - & - & 99.21 & 100.7 & - & - & 99.66 \\
\hline
\end{tabular}

a $\Delta \%=([$ reported value - observed value $) /$ reported value $] \times 100$.

b Average of 7 analyses.

c Personal communication, Mr. Joe Nelen, Smithsonian Institution (USNM), 1978.

d Average of 6 analyses.

e Abbey (1975) corrected for volatile loss.

$f$ Average of two analyses. 

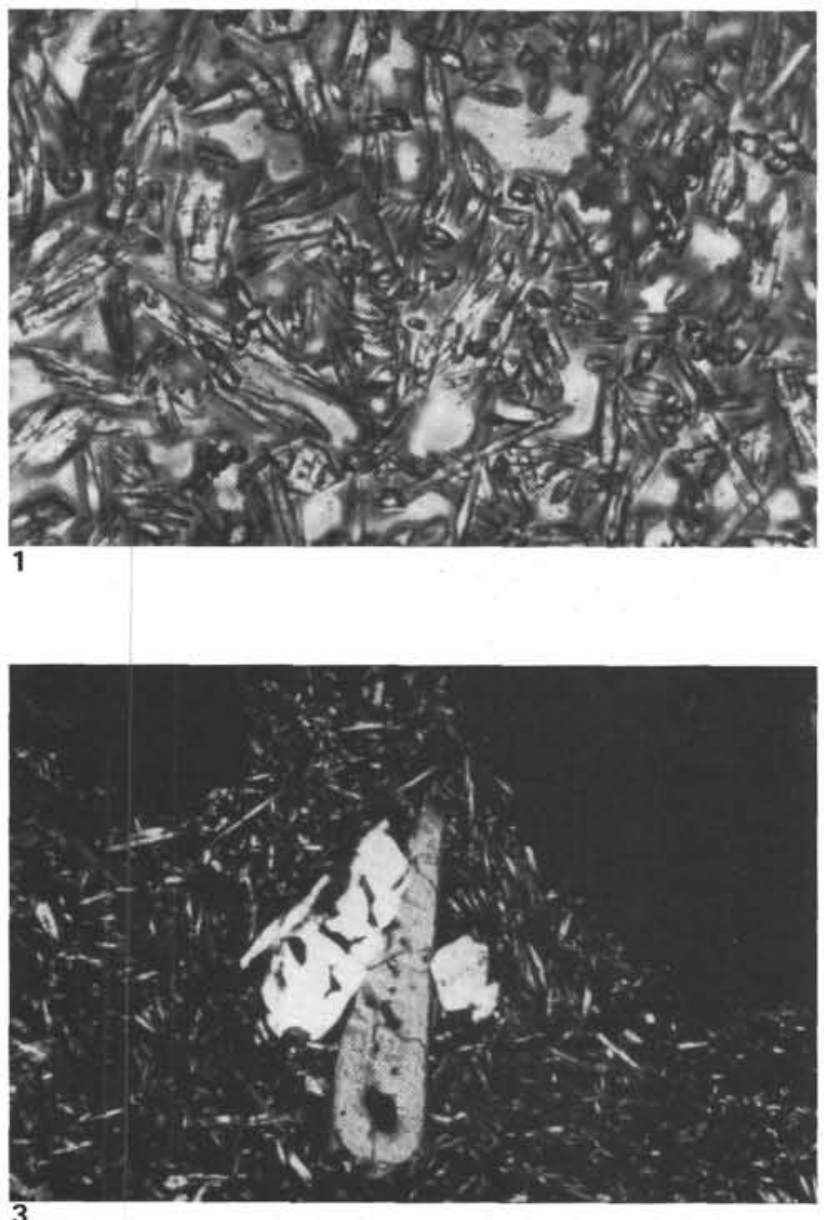
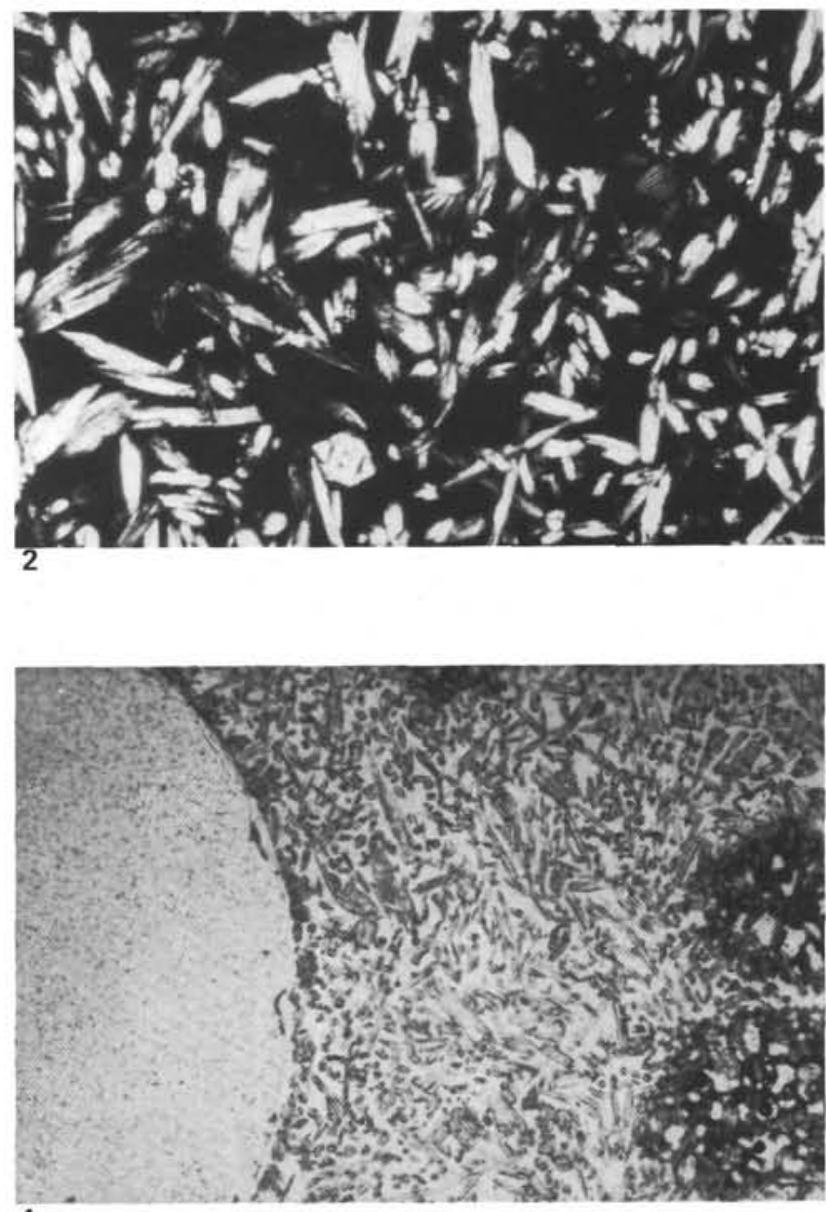

4

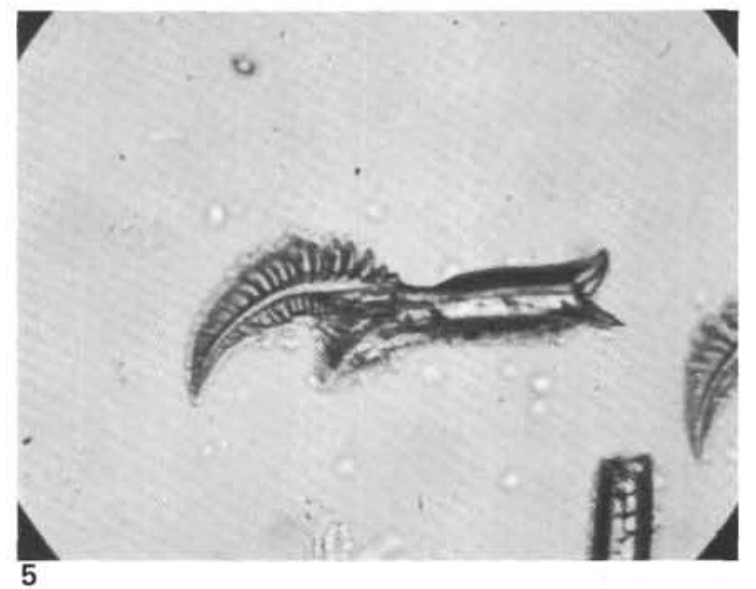

Plate 1. Photomicrographs of bronzite andesites, Hole 458.

Figure 1. Sample 458-30-1, 101-104 cm. Clinopyroxene crystallites in chill rind of bronzite andesite. Bladed habit characteristic. Note skeletal "cocks comb" quench crystals. Lack of Fe-Ti-oxides and plagioclase notable. Glassy mesostasis is pale brown owing to slight devitrification. Fresh glass is clear. Width of field $0.78 \mathrm{~mm}$, plane light.

Figure 2. Sample 458-30-1, 101-104 cm. Same as Figure 1 but under crossed nicols.
Figure 3. Sample 458-30-1, 101-104 cm. Orthopyroxene (bronzite) and clinopyroxene phenocrysts in chill rind of bronzite andesite. Groundmass as in Figures 1 and 2. Width of field $7.75 \mathrm{~mm}$, crossed nicols.

Figure 4. Sample 458-28-1, 142-146 cm. Outgassing "clots" in upper left corner and bottom center. Extremely fine grained plagioclase in clots with clinopyroxene and an Fe-Ti-oxide phase which provides color contrast. Large vesicles characteristic of chill rinds in these lavas. Width of field $7.75 \mathrm{~mm}$, plane light.

Figure 5. "Swallow tail" microlite found in sediments overlying volcanic section in Hole 458 . Width of field approximately $0.25 \mathrm{~mm}$. 

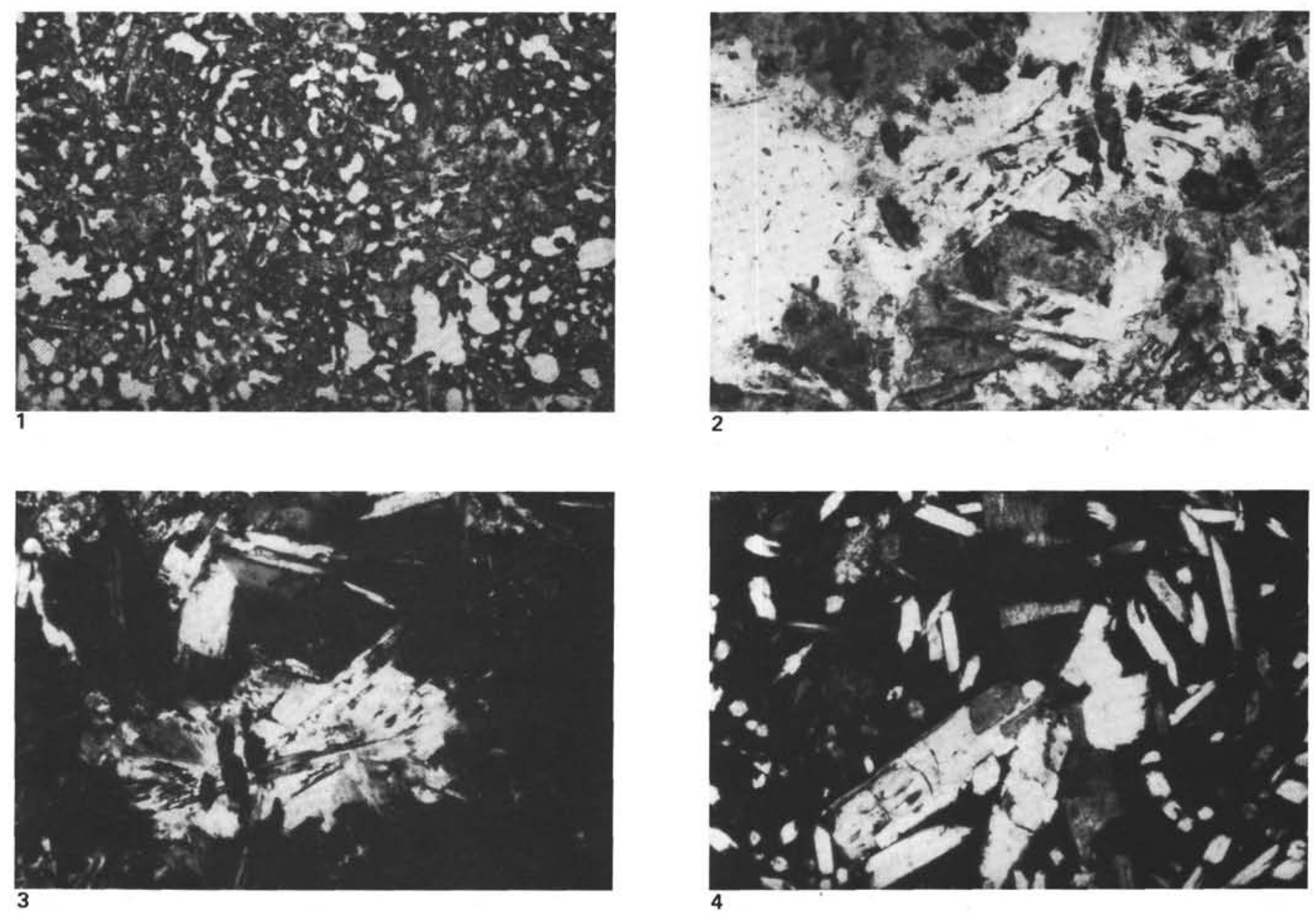

Plate 2. Photomicrographs of bronzite andesite, Hole 458.

Figure 1. Sample 458-28-1, 9-13 cm. Fine-grained pillow interior(?) showing typical high vesicularity. Compare with "clots" in Plate 1. Note vesicles are empty. Width of field $7.75 \mathrm{~mm}$, plane light .

Figure 2. Sample 458-31-1, 2-7 cm. Quartz-Fe-Ti-oxide-plagioclase "spherulite" in intersertal textured 2-pyroxene andesite. This par-

ticular "spherulite" larger than most others observed. Mesostasis surrounding "spherulite" is dusty pale brown slightly devitrified glass. Width of field $0.78 \mathrm{~mm}$, plane light.

Figure 3. Sample 458-31-1, 2-7 cm. Same as Figure 2 but crossed nicols. Note "spherulite" nucleated on plagioclase crystal.

Figure 4. Sample 458-28-1, 142-146 cm. Complex zoning of orthopyroxene in bronzite andesite. With of field $0.78 \mathrm{~mm}$, crossed nicols. 

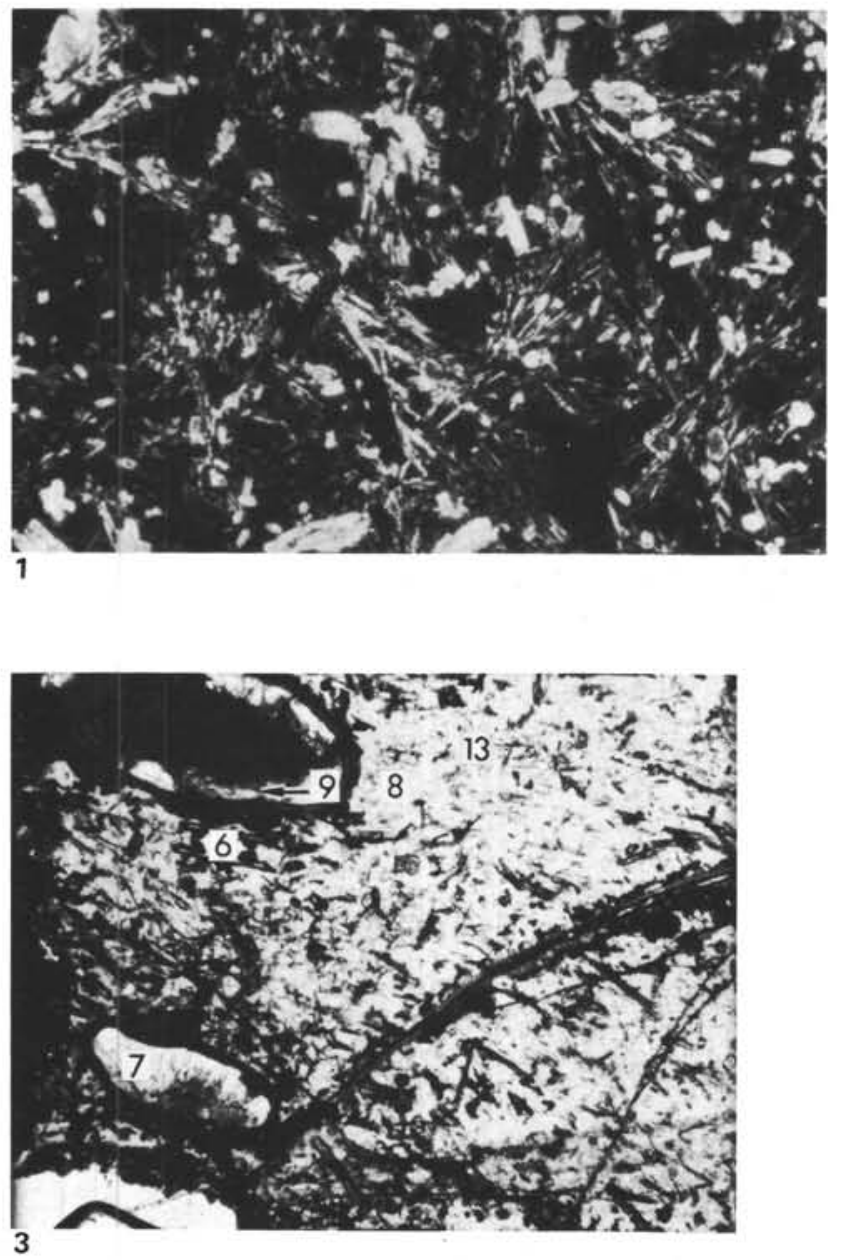

Plate 3. Spherulites, Fe-Ti-oxides, and alteration minerals in igneous rocks, Hole 458.

Figure 1. Sample 458-28-1, 9-13 cm. Spherulitic plagioclase with clinopyroxene. Width of field $1.94 \mathrm{~mm}$, crossed nicols.

Figure 2. Sample 458-46-1, 100-106 cm. Clay-filled vesicle in Unit 5 chill rind. Adjacent to vesicle wall is a layer of light clay which is sharply bounded by brownish green clay in interior. Remainder of photo shows plagioclase microlites and microphenocrysts in palagonitized and unpalagonitized glass. Width of field $3.8 \mathrm{~mm}$, plane light.
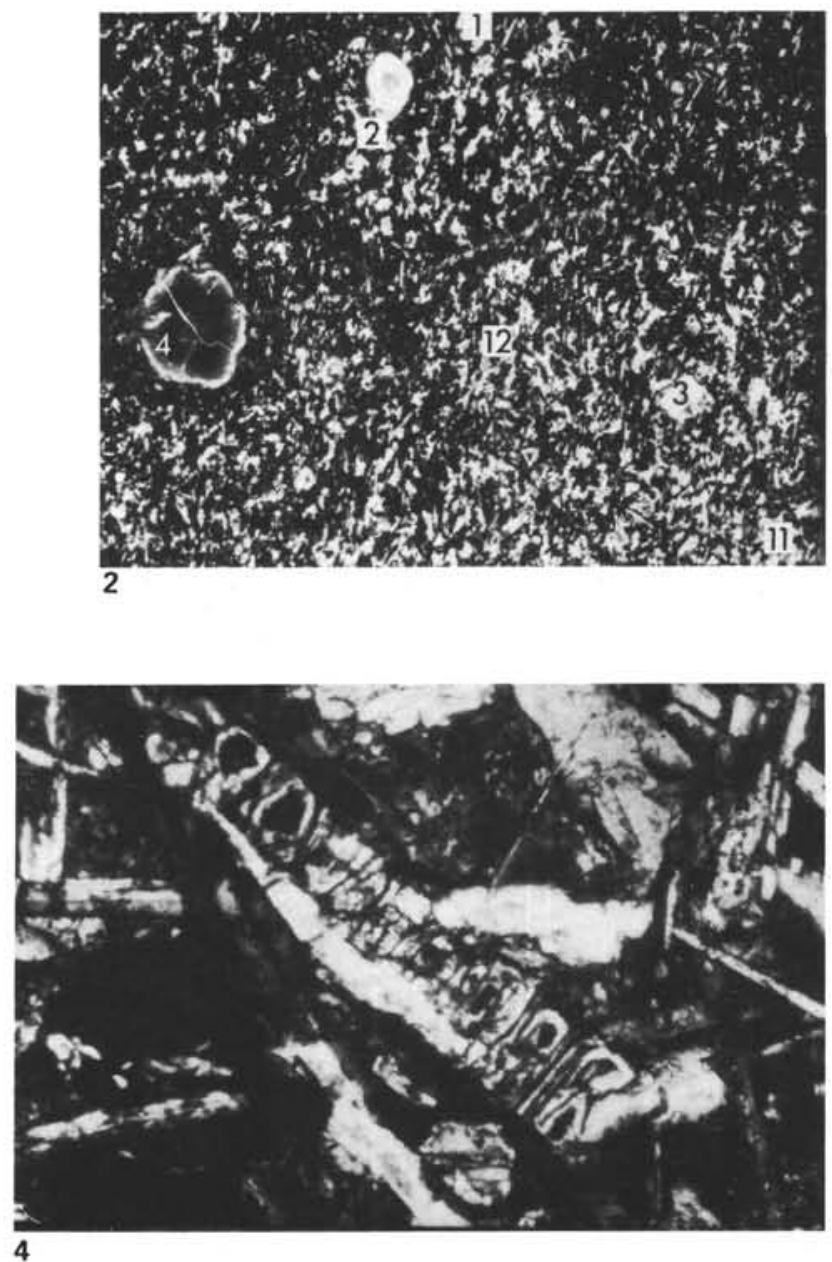

Figure 3. Sample 458-43-2, 34-37 cm. Zeolite-filled vesicles in chill rind of bronzite andesite. Note zeolites are superimposed on clay vesicle lining. Analysis of zeolite in lower left vesicle in Table 5. Analysis of skeletal orthopyroxene crystal just below upper left vesicle in Table 1. Most of photo pale brown to clear glass with clinopyroxene microlites. Analysis of glass in Table 4. Width of field $3.8 \mathrm{~mm}$, plane light.

Figure 4. Sample 458-33-1, 58-60 cm. Pseudomorph of clay after orthopyroxene in subophitic textured andesite. Note lack of alteration of clinopyroxene in upper center and mantling orthpyroxene pseudomorph. Remainder of photo plagioclase, quartz, and interstitial clay. Width of field 0.78 , crossed nicols. 


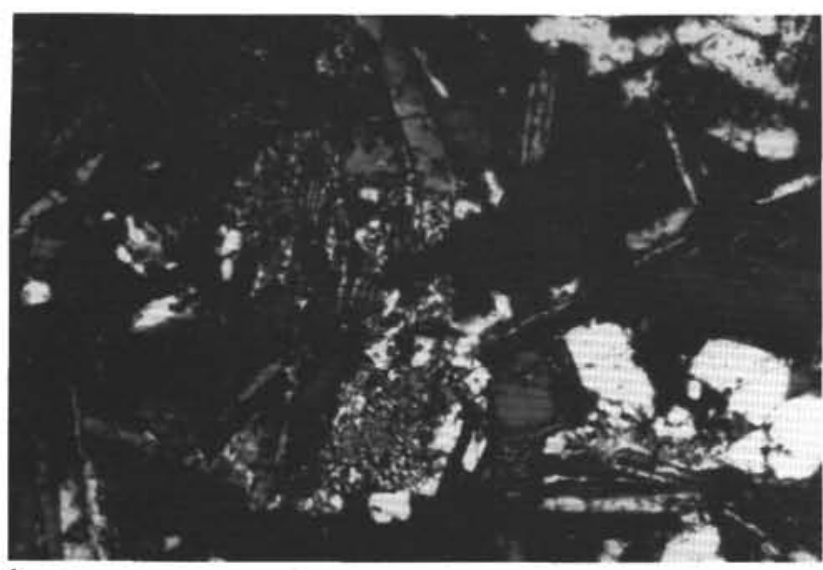

1

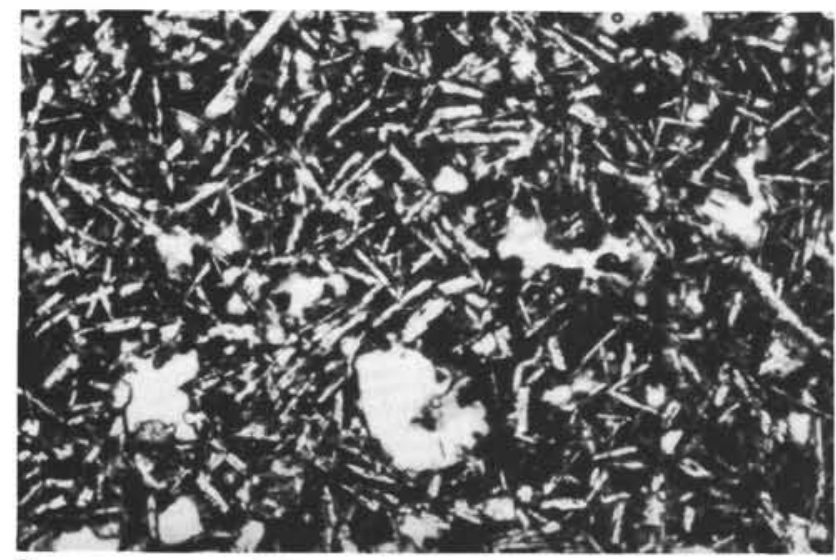

3

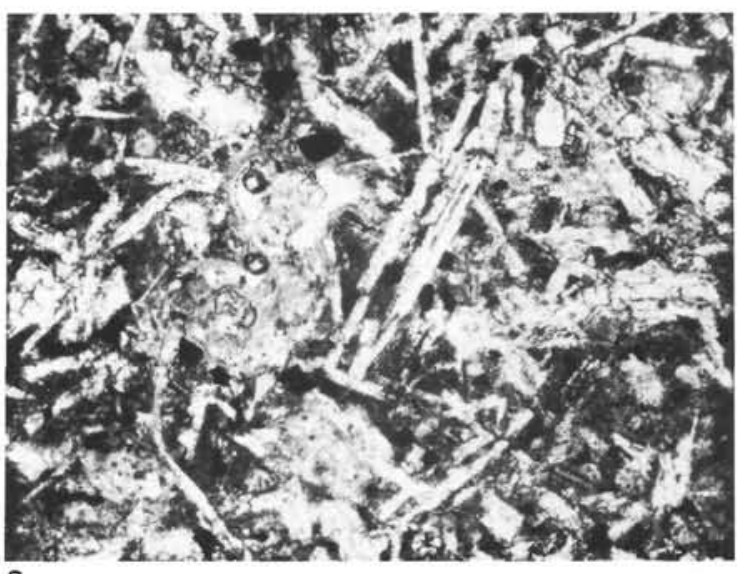

2

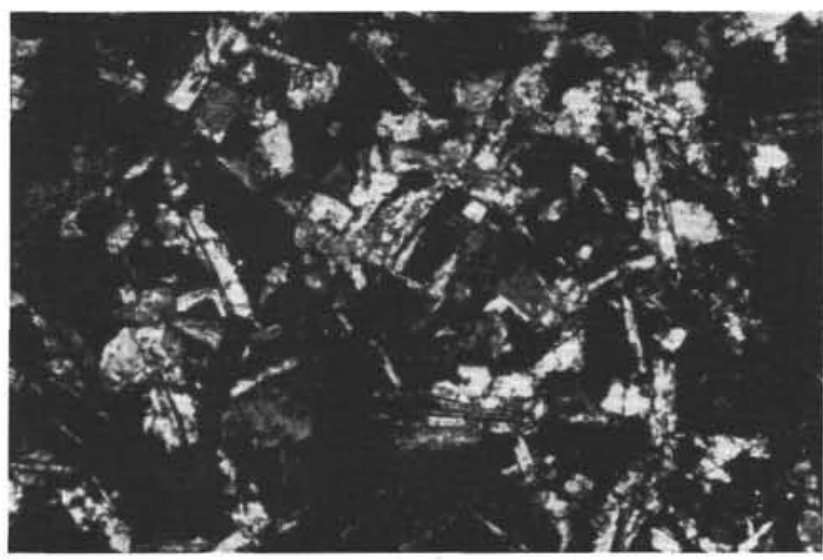

4

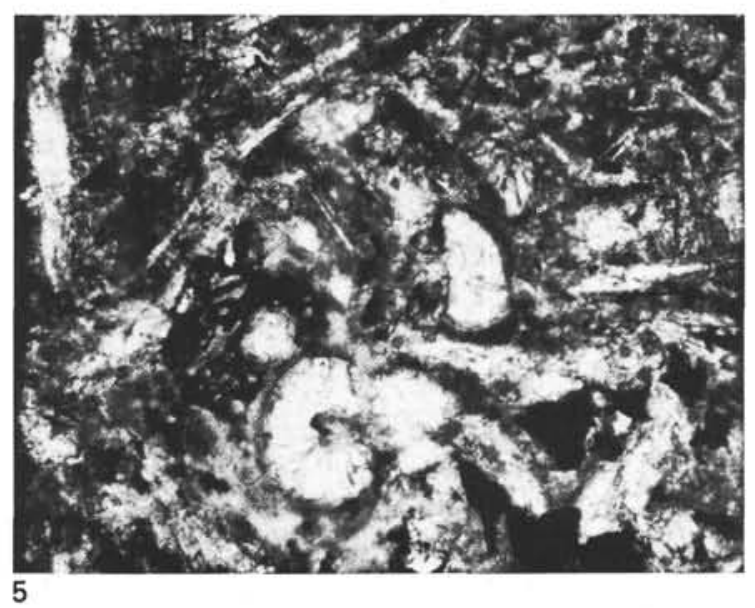

Plate 4. Quartz-alkali feldspar intergrowths and textures of basalts, Hole 459B.

Figure 1. Sample 459B-66-3, 3-4 cm. Micrographic intergrowth of quartz and feldspar in quartz-bearing tholeiitic andesite or quartz diabase. Note discrete quartz grains in upper left. Minor clinopyroxene in bottom center. Interstices between blocky feldspars lined with celadonite and clay. Width of field $1.94 \mathrm{~mm}$, crossed nicols.

Figure 2. Sample 459-71-1, 142-145 cm. Fe-Ti-oxide granules in intersertal texture characteristic of Petrographic Unit 5. Other phases include plagioclase, clinopyroxene, and altered mesostasis. Width of field $0.15 \mathrm{~mm}$, plane light.
Figure 3. Sample 459B-73-1, 6-9 cm. Typical diktytaxitic texture of plagioclase laths in Petrographic Unit 4. Most of interstitial and clinopyroxene material altered to clay. Note presence of Fe-Tioxide grains. Width of field $7.75 \mathrm{~mm}$, plane light.

Figure 4. Sample 459B-62-1, 44-46 cm. Clinopyroxene-plagioclase andesite. Width of field $7.75 \mathrm{~mm}$, crossed nicols.

Figure 5. Sample 459B-67-2, 106-109 cm. Cristobalite "buttons" in orthopyroxene-clinopyroxene andesite. Note skeletal and anhedral $\mathrm{Fe}-\mathrm{Ti}$-oxide grains. Cristobalite surrounded by devitrified mesostasis. Width of field $0.6 \mathrm{~mm}$, plane light. 

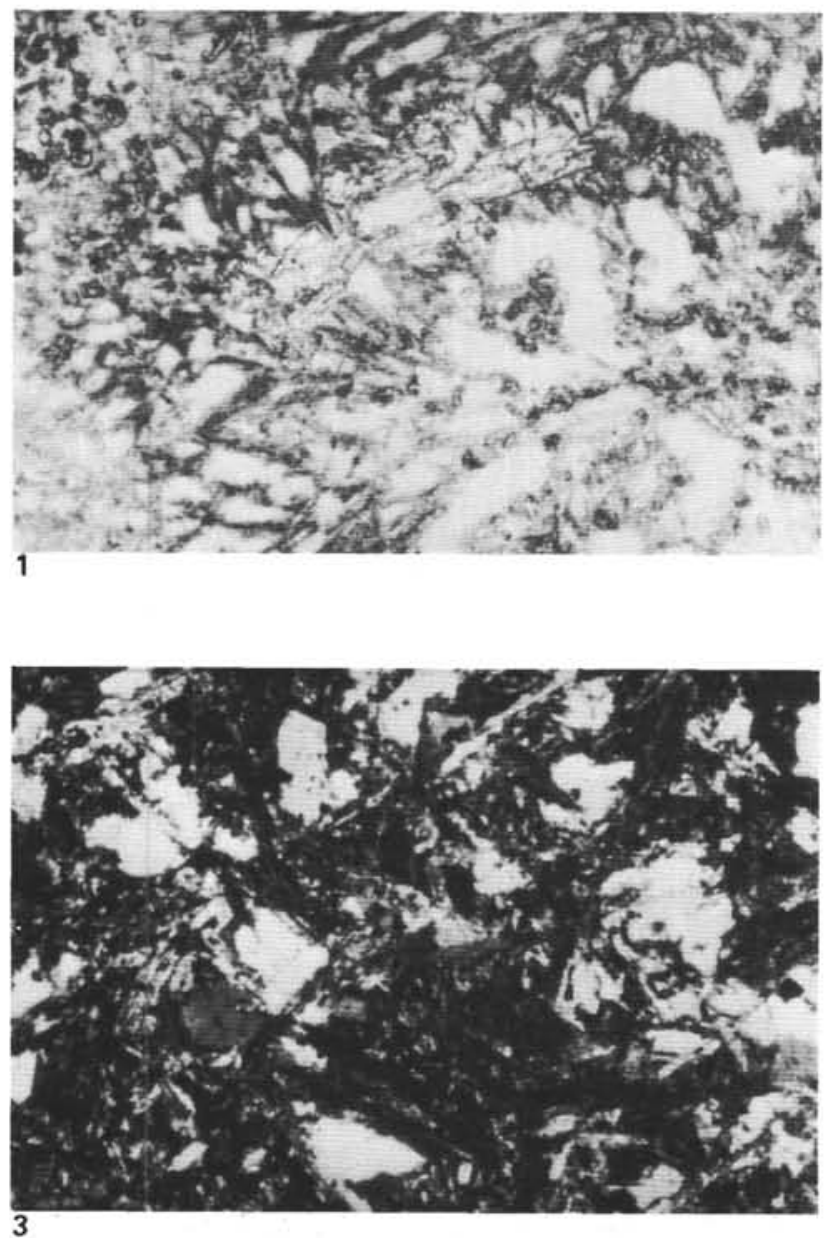

Plate 5. Photomicrographs of volcanic rocks from the Mariana Trench, Holes 460, 460A, 461, and 461A.

Figure 1. Sample 460-8-1, 148-150 cm. Highly vesicular pyroxene andesite(?). Compare Plate 2, Figure 1. Width of field $1.94 \mathrm{~mm}$, plane light.

Figure 2. Sample 460A-11-1, 20-26 cm. Pyroxene-plagioclase andesite(?). Mesostasis is brown glass slightly devitrified. Vesicles lined
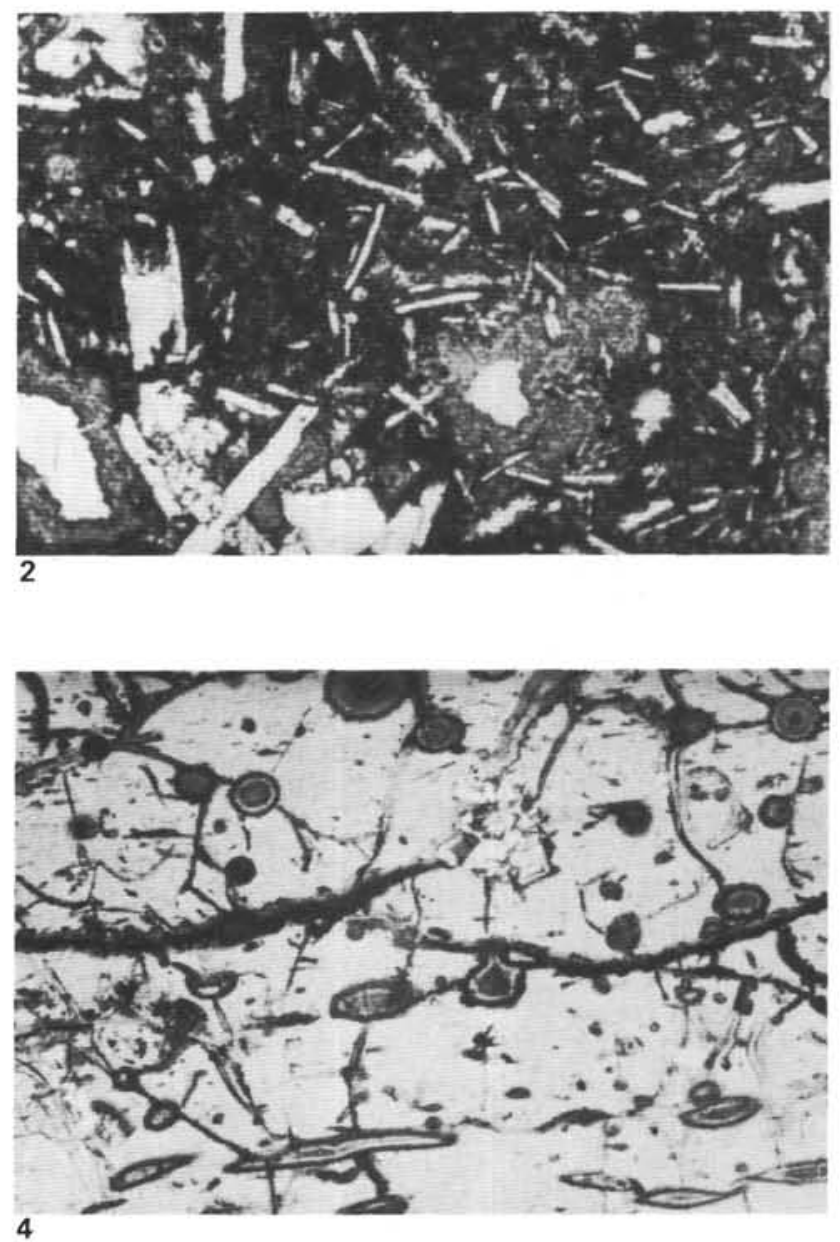

with palagonite-like substance. Width of field $1.94 \mathrm{~mm}$, plane light.

Figure 3. Sample 461-3-1, 62-64 $\mathrm{cm}$. Quartz-rich pyroxene andesite(?). Some primary clinopyroxene and plagioclase but most of photo comprised of secondary phase including quartz, clay, and chlorite. Width of field $1.94 \mathrm{~mm}$, crossed nicols.

Figure 4. Sample 461A-2-1, 85-86 cm. Vesicular pillow rind. Pale brown unaltered glass with clay-filled vesicles and fractures. Single microphenocrysts of clinopyroxene (lower center) and plagioclase upper left. Width of field $1.94 \mathrm{~mm}$, plane light. 